\title{
THE CUNEIFORM ORIGIN OF GENESIS AND A DATE FOR GENESIS 1
}

\section{Carey F. J. Harmer}

$* * * * *$

\begin{abstract}
PART 1 argues for a paradigm shift to the conclusion that Genesis 1 to 37 was originally written in cuneiform; that Genesis 1-4 was written c. 2850 BC and Chapters 5 to 37 at about the times of the events recorded.
\end{abstract}

PART 2 proposes a systematic transcription error due to misreading of the cuneiform signs, that reduces the ages of the patriarchs in Genesis 5 to a more likely range; if validated, confirming the thesis of PART 1.

The proposed early dating is based on archaeological evidence without religious presuppositions; places the origin of the Judaeo-Christian world-view at the dawn of civilisation; and does not conflict with any scientific discovery or any Christian doctrine.

PART 3 introduces a second paradigm shift, to the interpretation that Genesis 1 recounts Six Days not of Creation but of Revelation, signposting a path connecting Genesis 1 with current scientific knowledge, and with the origin of science.

Keywords: Genesis, colophons, Sumerian, cuneiform, antediluvians, JEDP, paradigm shift.

[There is an OVERVIEW at the end of the paper]

\author{
$* * * * *$ \\ PART 1 \\ GENESIS 1:1 TO 37:2A WAS WRITTEN IN CUNEIFORM \\ AND (EXCEPTING CHAPTERS 1 TO 4) \\ AT ABOUT THE TIME OF THE EVENTS RECORDED \\ $* * * * *$
}

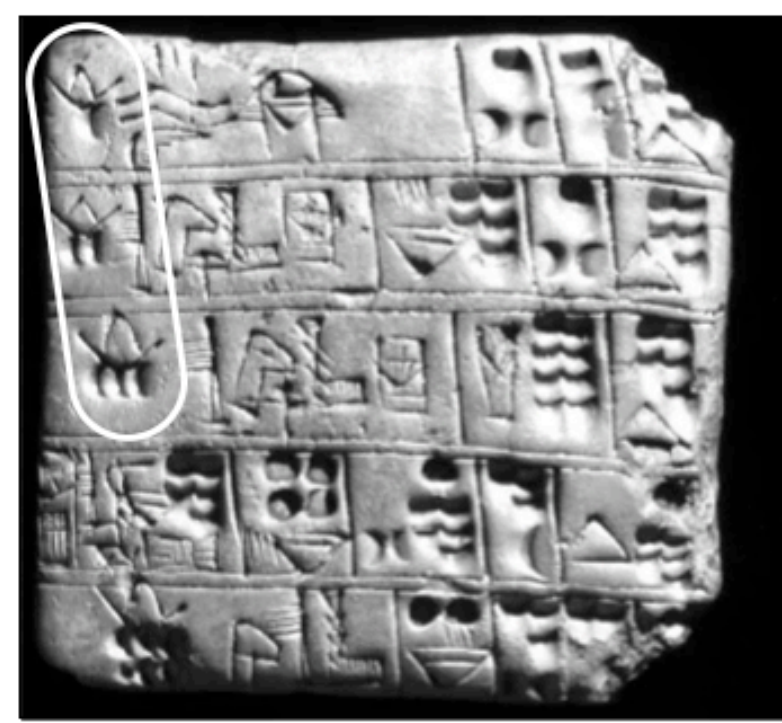

FIGURE 1. This clay tablet from ca. $3000 \mathrm{BC}$ shows how the 'days' in Genesis 1 could have been written.

The writing is Archaic Sumerian, (early clipart) before the development of cuneiform and sexagesimal numbers.

Notice the signs enclosed by the white oval.

The 'W' sign (the sun rising in the mountains); $u_{4}=$ 'day'.

The circular and crescent impressions are number tokens for 10 and 1 respectively.

The left-hand signs, reading downwards:

Day 1, Day 2, Day 3; no day sign, Day 5.

To the right of Days 2, 3 and 5: the head of a donkey anšè and a vertical sign for barley še.

In lines 2, 4 and 5 the inverted triangle sign nind $a=$ 'bread'. Size $7.8 \times 7.8 \mathrm{~cm}$.

British Museum 116730 . 


\section{This Sumerian Clay Tablet Initiates a Paradigm Shift}

This tablet, ${ }^{1}$ in the British Museum collection, ${ }^{2}$

- was found in Jemdet Nasr, the site of an ancient city about 100 miles from Ur, in 1925;

- is written in Archaic Sumerian, the lines reading from left to right;

- is dated c. $3000 \mathrm{BC}$, over a thousand years before Abraham,

- in the period of the Bronze Age inventions mentioned in Gen. 4:21, 22;

- it details the issue of several types of rations for five days,

- and gives the name of the recipient or the destination of the issue.

As one of many similar tablets, it is prima facie evidence that Genesis 1 could have been written in the Early Dynastic 1 (EDI) period, 2900-2750 BC, placing the origin of the JudaeoChristian world-view at the dawn of civilisation. The series of numbered days in FIGURE 1 is striking visual confirmation.

This assertion is met by many a Hebrew scholar with dismissive incredulity, because it contradicts the 'standard model' — the Documentary Hypothesis (JEDP) — which assumes hundreds of years of oral transmission before Genesis was put into writing.

Resurrecting an idea that for nearly a hundred years has been ignored by academia and rejected by most of the conservative scholars who have considered it, requires some justification. ${ }^{3}$ It is this: the long period of oral transmission which ignores the invention of writing, is a demonstrably false paradigm assumption. The evidence for the proposed paradigm shift is textual, linguistic, archaeological and mathematical, has been in the public domain for over fifty years, and, importantly, is open to proof or disproof.

A paradigm acts like a local anaesthetic: information from the dead area is blocked off from the brain. In real life it promotes an inability or refusal to see beyond the current models of thinking. In this case the dead area is archaeology and the development of writing.

\section{Paradigm shifts}

Over the last two hundred years the Christian understanding of scripture has got out of step with the progress of scientific knowledge. No generally agreed way has been found of reconciling Genesis with the discoveries of fossils, the DNA of the hominids, and the archaeology of ancient civilisations.

Something similar happened around the time of the Reformation, when the geocentric planetary system, which was universally believed to be taught in the bible, was found to be incompatible with the new and scientifically incontrovertible heliocentric system of Copernicus. A paradigm shift solved the problem.

This paper argues for two paradigm shifts: first, to the conclusion that Genesis $1-37$ was written in cuneiform on eleven (series of) clay tablets: Gen. 1:1-5:1 in EDI, and 5:2-37:2a around

\footnotetext{
<https:/www.britishmuseum.org/collection/object/W_1925-0110-28. The photo on the British Museum website is laterally inverted and upside-down.

2 In FIGURE 1 and elsewhere: Sumerian and Akkadian $\check{s}$ is pronounced $s h$; subscripts and accents are the Assyriologists' convention to denote which of several homophones is intended.

3 P. J. Wiseman, New Discoveries in Babylonia about Genesis (London: Marshall, Morgan \& Scott, 1936).

$<$ biblemaths.com/pdf_wiseman.pdf. Hereafter $N D B G$. Several reviewers have asked what was said about Wiseman's theories at the time. The answer is: nothing. The book was written for the Christian public, was not widely known, and was not discussed in academia.
} 
the time of the events recorded; 4 and second, to the interpretation that Genesis 1 is a sort of early six-day-seminar. The Genesis references to the tablets are given in TABLE 1 on page 9.

\subsection{The current paradigm has many 'dormant anomalies'}

They are unexplained observations that 'survive for a long period during which no competing alternative has shown itself capable of resolving the anomaly'. ${ }^{5}$ A paradigm shift is evidenced when the new paradigm includes the phenomena explained by the old one and also resolves its 'dormant anomalies'.

- In the same way that the shift in the perihelion of Mercury could not be explained by Newton's Laws, and waited two hundred years for Einstein's General Relativity, so in two hundred years of the JEDP paradigm there has been no explanation of why there are no more toledoth - (NIV) accounts or (AV) generations - after Gen. 37:2.

- 'Nowhere in the Ancient Orient is there anything [like] the elaborate history of fragmentary composition and conflation ... as the documentary hypotheses would postulate.' 6

A 'dormant anomaly' resolved by this thesis is indicated by the symbol $\$$; there are over twenty in this paper.

\subsection{Contrary evidence is excluded by}

\section{a. academic groupthink}

- Thomas L. Thomson cites and critiques 400 authors to prove the non-existence of Abraham, but omits P. J. Wiseman. ${ }^{7}$

- Zygmont Bauman, a Professor of Sociology: 'We must challenge "any prevailing ideological fashion of the day whose commonality is taken for the proof of its sense." "8 Gordon Wenham admits that JEDP relies on just such a consensus. ${ }^{9}$

- C. S. Lewis, a Professor of Mediaeval Literature: 'The reconstruction of the history of a text, when the text is ancient, sounds very convincing. But ... the results cannot be checked by fact. ... The men who know the facts are dead and can't blow the gaff.' 10

- Bede, in his Ecclesiastical History of the English People, written in AD 731, quotes Pliny and other Latin sources. In his time Latin had been written for over a thousand years, and no historian thinks that Bede received his sources by oral transmission. But although it has been common knowledge since the 1960s that writing was invented fifteen hundred years before Moses, ${ }^{11}$ Pentateuchal scholars have continued to assume hundreds of years of oral transmission before Genesis was put into writing. ${ }^{12}$

\footnotetext{
4 In the absence of contrary archaeological evidence, this paper follows the traditional view that Moses was the writer of the Hebrew text of the Pentateuch.

5 L. Laudan, Progress and Its Problems: Towards a Theory of Scientific Growth (Berkeley: University of California Press, 1977).

6 Kenneth A. Kitchen, Ancient Orient and Old Testament (London: Inter-Varsity Press, 1966): 19.

7 Thomas L. Thompson, The Historicity of the Patriarchal Narratives: the Quest for the Historical Abraham (Harrisburg: Trinity International, 2002): 336-378.

8 Zygmont Bauman, 'On Writing: On Writing Sociology' in Theory, Culture \& Society (2000): 79.

9 Gordon Wenham, Word Biblical Commentary, Vol. 1: Genesis 1-15 (Grand Rapids: Zondervan, 2014), xxxv.

10 C. S. Lewis, 'The Funeral of a Great Myth' in Christian Reflections (London: Geoffrey Bles, 1981; repr. London: HarperCollins, 1991): 117-118.

11 For example, Samuel N. Kramer, The Sumerians: Their History, Culture and Character (Chicago: University of Chicago Press, 1963): 239.

12 For example, in a standard work first published in 1959, 'The long process of oral transmission through which the traditions passed'. John Bright, A History of Israel, 4th edn. (Philadelphia: Westminster, 2000): 75.
} 


\section{b. neglect of archaeology}

- Although R. K. Harrison's Introduction to the Old Testament (1969) has 17 pages on chronology from Adam to Abraham, ${ }^{13}$ and another 16 pages on the archaeological background down to Joseph (and supports this thesis), Gordon Wenham's volume (2014, nearly 50 years later), typical of many, has little on archaeology apart from the Babylonian epics, and nothing about the development of writing.

- John Walton, a Hebrew scholar, assumes that Genesis 1 reflects the culture of the Akkadian epics (about the time of Abraham), passing over the discoveries of hundreds of clay tablet writings dating from a thousand years earlier in Abraham's hometown of Ur. ${ }^{14}$ The reviewer of the book, another Hebrew scholar, in Perspectives on Science and Christian Faith did not notice, or declined to comment on this unscientific disjunction; ${ }^{15}$ - two neat examples of the anaesthetic effect of the paradigm.

- In marked contrast, Carol A. Hill, a geologist and so not indoctrinated in the theologians' paradigm, in the same journal had casually pointed out: 'We can by no means assume that all of the accounts and incidents mentioned in the book of Genesis were dependent on oral tradition before the time of Moses.' 16

Summarising the academic line-up: on the one side stands the internationally respected Assyriologist Professor Donald Wiseman, as far as I know the only cuneiform scholar who has

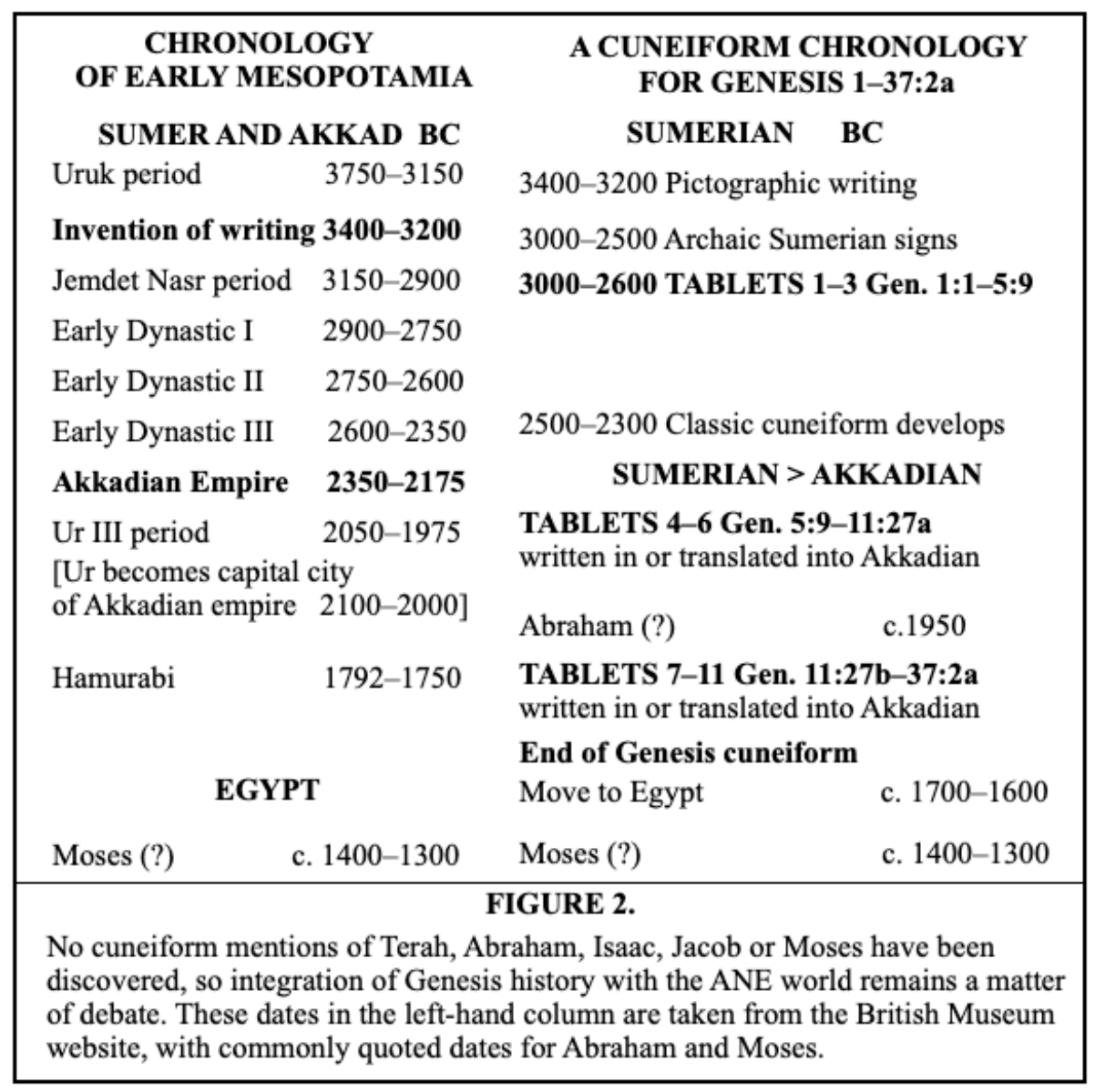

\footnotetext{
13 Roland K. Harrison, Introduction to the Old Testament (Grand Rapids: Eerdmans, 1969).

14 John H. Walton, The Lost World of Adam and Eve: Genesis 2-3 and the Human Origins Debate (Downers Grove: InterVarsity Press, 2015).

15 Walton, reviewed by August H. Konkel, Perspectives on Science and Christian Faith (PSCF) 68.1 (2016): 67-68.

16 Carol A. Hill, ‘A Time and a Place for Noah', PSCF 53.1 (2001): 23-40.
} 
written about Genesis 1, suggesting that Genesis was originally written in cuneiform, ${ }^{17}$ against a hundred Hebrew scholars whose training has not included Sumerian or Akkadian and ignores the possibility that the patriarchs might have written their history in their mother tongue.

\section{Evidence for an Early Dynastic I date for Genesis 1:1-2:4}

FIGURE 2 gives an outline of the dates of this period; from the invention of writing to Abraham is a thousand years. Considering that writing was invented c. 3000 BC in Sumer, where the patriarchs lived and where Sumerian epics are known from 2600 BC, the theory that Genesis 1 might have been written in Sumerian between those two dates is not obviously far-fetched.

\subsection{Writing was known before the flood.}

The emperor Assurbanipal (c. 600 BC) wrote, at least 2000 years after the flood, when he was a schoolboy:

I have read the artistic script of Sumer (and) the dark (obscure) Akkadian, which is hard to master, (now) taking pleasure in the reading of the stones ... from before the flood. ${ }^{18}$

\subsection{The Bronze Age Sumerians c. 4000-3000 BC}

As Terah (c.1900 BC) and presumably his ancestors lived in Ur (Gen. 11:31) in the land of Sumer, their ancestral language would have been Sumerian.

The Bronze Age Sumerians were a highly intelligent people.

They invented the brick mould, the potter's wheel, the wagon wheel, the plow, the sailboat, the arch, the vault, the dome, casting in copper and bronze, riveting, brazing and soldering, sculpture in stone, engraving, and inlay. ${ }^{19}$

In their towns they had lavatories and sewers; ${ }^{20}$

and in Uruk (about $50 \mathrm{~km}$ from Ur) c. 3400-3200 BC they invented writing. (See §7.1.d).

The earliest writing was pictographic (FIGURE 3), c. 3500 BC. From 3500-2500 BC the pictograms developed into Archaic Sumerian with its symbolic representations of objects, as in FIGURES 4 (3300-3100 BC), 1 (3000 BC) and 8 (2600 BC).
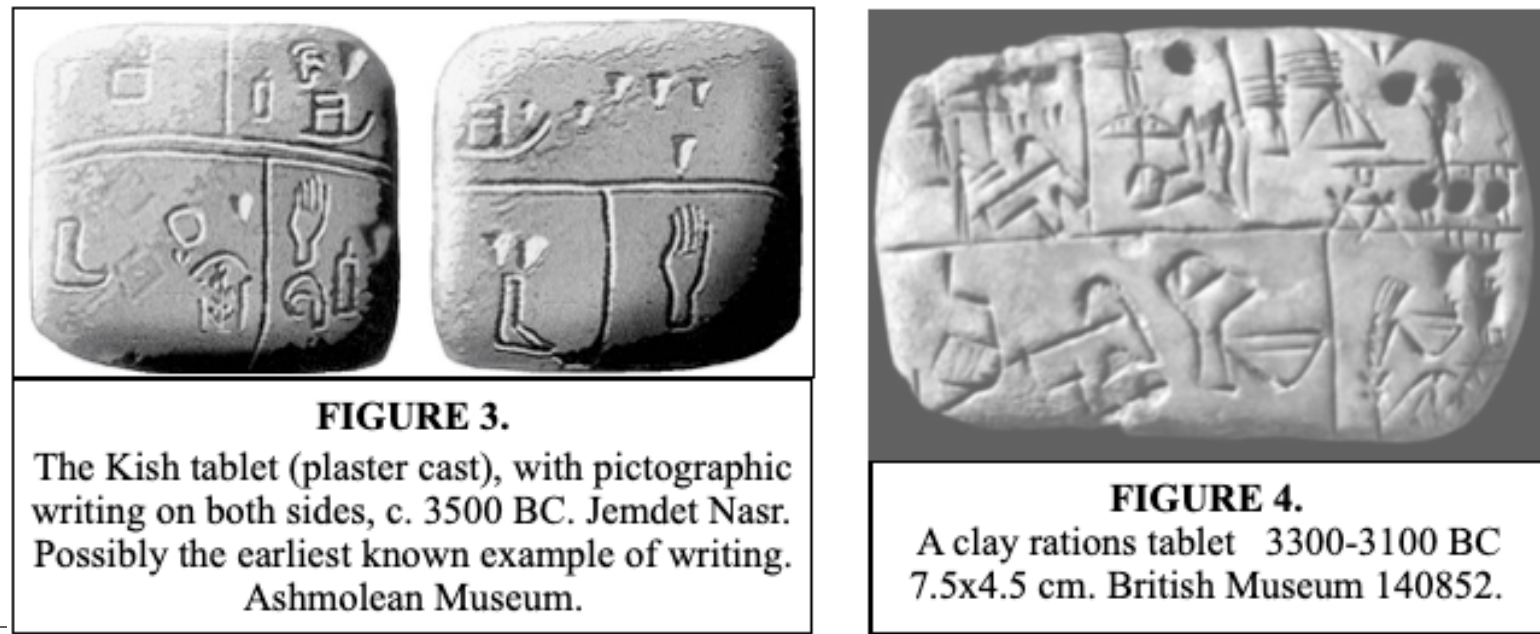

FIGURE 4.

A clay rations tablet $3300-3100 \mathrm{BC}$ $7.5 \times 4.5 \mathrm{~cm}$. British Museum 140852 .

17 D. J. Wiseman, 'Creation Time_-What Does Genesis Say?' Science and Christian Belief (1991), 3: 25-34; and books in §6.1.

18 D. D. Luckenbill, Ancient Records of Assyria and Babylon, Vol. 2 (Chicago: University of Chicago Press, 1927 ): 379.

19 Kramer, 3-4. Unreferenced statements in this paper about Sumerian and Akkadian are common knowledge in the field and can be found in general articles in Wikipedia.

20 A. R. George, ‘On Babylonian Lavatories and Sewers', Iraq 77 (2015): 75-106. 
Peter Damerow raised the question of the development necessary for a written language composed of signs mostly of objects and numbers to convey spoken language or stories. ${ }^{21}$ Taking the point, we consider whether Archaic Sumerian was a practical literary vehicle for Genesis 1.

Archaic Sumerian had several hundred signs. Being an agglutinative language signs could be strung together to make verbs and abstract concepts. In FIGURE 4 (lower line, centre) a 'head' sign combined with a 'bowl' sign, first meant [a list of] 'rations', later came to mean 'eat', and finally, 'consume'. Concepts could be built up from several signs and sounds. 'Heaven-and-earth' and 'kiln-burnt brick' (§4.2.c) are further examples. The Sumerian scholar John Halloran writes 'The structure and thinking behind the Sumerian vocabulary is to me a thing of beauty'.22

The Sumerians were very keen on lists; in school future scribes were taught to copy and memorise lists of words, tools, occupations, animals, everything.

We observe that:

- $\quad$ in Genesis 1 the only 30-odd nouns, 18 verbs, 10 adjectives, and the other words and numbers, would all be in everyday use in that early context.

- Professor Donald Wiseman stated that 'The language [of Genesis 1] is clear and simple... . Only 75 basic Hebrew words (roots) are employed and all are represented by their equivalents in ... Sumerian' ${ }^{23}$

- The tablet FIGURE 1 appears to have been written by a farm or stock manager, indicating that the upper servant class had functional literacy.

- The tablet lists the day of the week, items, and what is to be done with them on each day. Genesis 1 has the same form as this early tablet: a list of days with the corresponding actions.

- Creation stories (for example, Gilgamesh, Enuma Elish) are a familiar genre of Sumerian literature.

- 'Sumerian thinkers classified the world into the following categories: domestic animals, wild animals, ... birds, ... fishes, trees, plants, vegetables, and 'stones'. '24 A very similar classification, itemised in PART 3 §3.2.a, is used in Genesis 1 , and four rivers and three 'stones' are listed in Gen. 2:10-14.

These observations show that in vocabulary, thought, form, and usage Archaic Sumerian appears to be feasible and even likely as the original script of Genesis 1 .

\subsection{A 'written account' in Early Dynastic I}

I invite you to come with me on a trip in thought back to the Uruk period, 4100-3500 BC, to the Zagros mountains of Iraq. Primitive tribal groups are living in small villages using their distinctive Ubaid-style pottery. Among them is a small clan of worshippers of the One True God. ${ }^{25}$ In the Early

\footnotetext{
21 Peter Damerow, 'The Origins of Writing as a Problem of Historical Epistemology' CDLJ (2006): 1.

22 John A. Halloran, Sumerian Lexicon: A Dictionary Guide to the Ancient Sumerian Language, (Los Angeles: Logogram, 2006$), 1$. Quoted references to $<\mathrm{http}$ //www.sumerian.org/sumerian.pdf.

23 Donald J. Wiseman, 'Creation Time—What Does Genesis Say?' Science and Christian Belief (1991): 25-34.

24 Kramer, 90.

25 Perhaps recently implanted with the image of God in a 'cognitive big bang', Richard E. Ecker, PSCF 50.4 (1998): 284-285; or a 'cultural initiation', David L. Wilcox, PSCF 60.1. (2006): 35; or Denis Alexander's 'special revelation' in Creation or Evolution - Do We Have to Choose? (Oxford: Monarch, 2008): 236-237; or 'lifted up', Peter J. Bussey, Science \& Christian Belief 32.1. (2020): 27.
} 
Bronze Age they migrate down to the growing civilisation in the fertile alluvial plain of Sumer, and settle there. ${ }^{26}$

Perhaps in the flourishing town of Ur, the clan makes a hard copy of their earliest history, TABLET 1 (actually a series of six tablets), which we know as Gen. 1:1-2:4.

They write TABLET 2 with the history of their descent and of God's dealings with them (Chapters 2-4), and in Gen. 5:1 they draw attention to their use of the latest technology - it is 'a written account' — as our emails say, 'sent from my iPhone'. ${ }^{27}$

Chapter 4 gives a genealogy down to Noah noting the EDI developments of Sumerian civilisation such as the harp and the lute and bronze and iron tools. The description of this record, TABLET 2 (but none of the subsequent tablets), as a written account in Gen. 5:1 suggests that it was written in that same period, when writing was another of these recent inventions. Hundreds of years later, when writing was in common use, it would be a pointless remark $\$$

The non-mention in Genesis 1 of any of the Sumerian or Akkadian names for the sun or the moon, 'the two great lights', or of any of their gods $\boldsymbol{\$}$, also supports a very early date.

By 2600 BC Sumerian religious poems and epics, such as Gilgamesh, had appeared, giving a development-of-writing terminus ad quem for Genesis 1 . There appears to be no archaeological or linguistic reason why Genesis 1 could not have been written in EDI (2900-2750 BC). In the absence of any estimate of the date by a cuneiform scholar taking the tablet in FIGURE 1 and the many similar tablets into account, this author tentatively suggests

\section{A DATE FOR GENESIS 1:1-2:4 - 2850 \pm 150 BC.}

TABLET 1 (Gen. 1:1-2:4) and TABLET 2 (Gen. 2:5-5:1a) and probably TABLET 3 (Gen. 5:1b-6:9a) would have been written in Archaic Sumerian; TABLET 2 at the same time as TABLET 1 or later in EDI. TABLET 3 was written shortly before the Flood.

From about 2500 BC, Archaic Sumerian evolved into Classic Sumerian, the all-wedge-shaped writing in FIGURE 9.

In the time of Abraham (c. $1950 \mathrm{BC}$ ), although cuneiform was now so complex that a scribe needed years of training, knowledge of about two hundred signs would give functional literacy. If a household servant could scribble a rations list in $3000 \mathrm{BC}$, it is likely that a thousand years later in a civilised society the children of the better-off, as in Greece and Rome, were taught to read and write.

Although according to Gen. 13:2 and 14:14 Abraham was a wealthy man owning an agribusiness with 300 male workers, and brought up in a city with a thousand years of literate urban civilisation, the paradigm has left the idée fixe in the academic world that Abraham was a more-orless illiterate herder $\$ .28$ There is no reason to suppose that Abraham was not an educated man. The translations of Assurbanipal's schoolboy tablet and the tablet in FIGURE 1 were published in 1927; evidence that the patriarchs were probably literate has been around a long time.

\footnotetext{
26 David Rohl, A Test of Time Volume 2: Legend - The Genesis of Civilisation (London: Century, 1998): 136-139. Although Rohl's reconstruction is followed here, the thesis of this paper does not require a choice between his New Chronology and its mainstream rivals.

27 'Hebrew sefer ... specifically denotes a written document, not an oral composition.' Nahum M. Sarna, The JPS Torah Commentary: Genesis (Philadelphia: The Jewish Publication Society 5749/1989): 41.

28 For example, Bright, 81. '[the patriarchs] were semi-nomadic breeders of sheep and other small cattle.'
} 
From $2300 \mathrm{BC}$ the Akkadians gradually overran the land of Sumer, from the north to the south. Ur is situated in the south of the country. While Sumerian is a language isolate, Akkadian is a Semitic language. '(Ca. 2600 BC), scribes who bore Semitic names composed some of the earliest known Sumerian literary texts', ${ }^{29}$ which suggests they quickly adopted the Sumerian writing system.

An unusual relationship called a Sprachbund developed, with words and grammatical features moving in both directions - causing headaches for both ancient and modern students of the languages. Sumerian and Akkadian were both spoken '[with] widespread bilingualism'. ${ }^{30}$ Being an educated man, Abraham could have been bilingual. Sumerian is believed to have died out as a spoken language by about $1800 \mathrm{BC}$; but it could have continued in family use for much longer. ${ }^{31}$

The clan of Abraham may have continued to record their sacred histories in their ancestral language, in which case they would probably at a later date have been copied and translated into Akkadian; or they may have been originally written in Akkadian (see FIGURE 5).

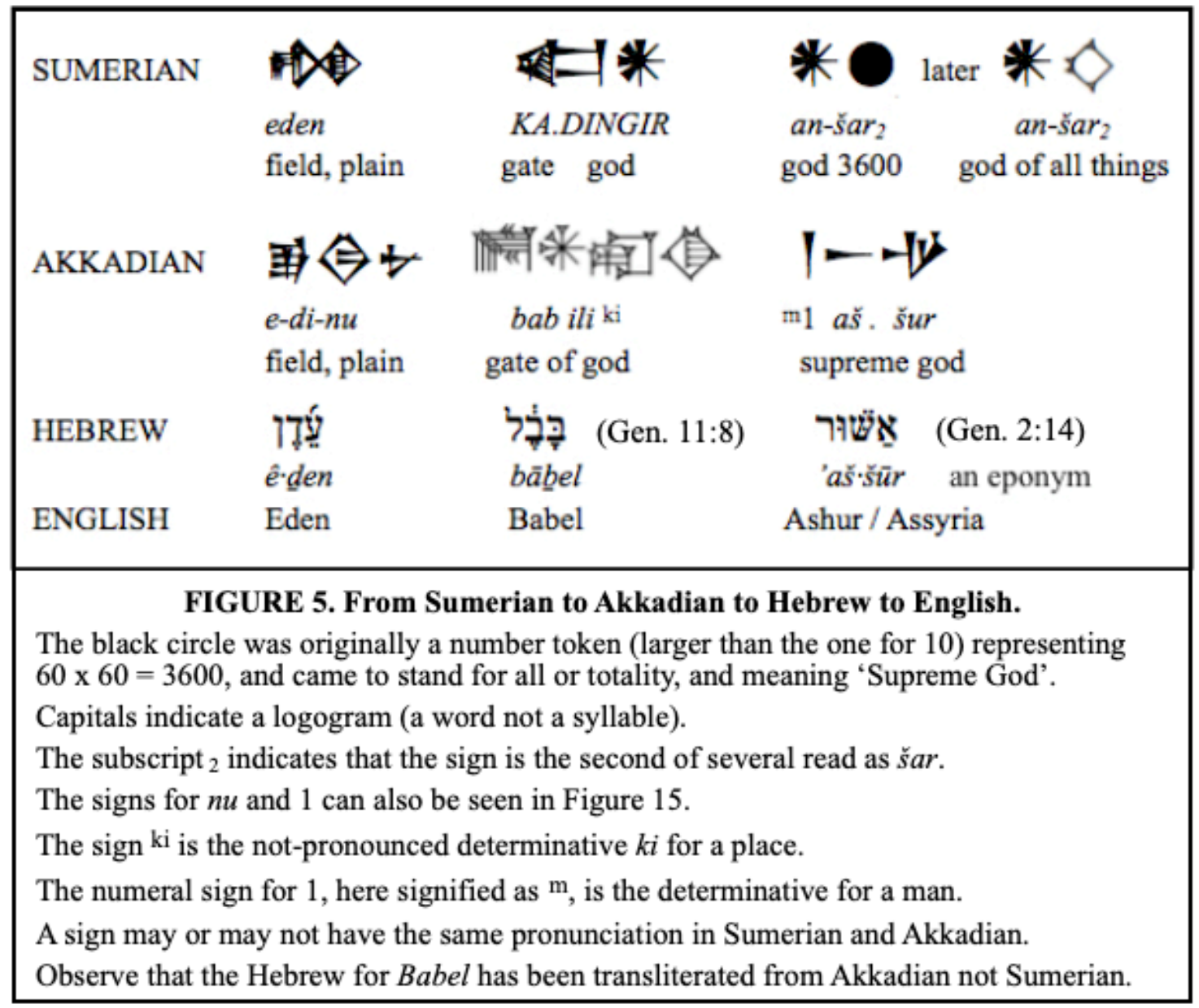

\section{Evidence for Contemporary Writing of Genesis 5:2-37:2a}

Having noted archaeological evidence that Genesis might have been written in cuneiform, we now look for confirmatory evidence in the text.

29 Christopher Woods, 'Bilingualism, Scribal Learning, and the Death of Sumerian' in Seth L. Sanders, ed., Margins of Writing, Origins of Cultures (Chicago: University of Chicago Press, 2006): 91-120, esp. 100-101.

30 D. Deutscher, Syntactic Change in Akkadian: The Evolution of Sentential Complementation (Oxford: Oxford University Press, 2007): 20-21.

31 Although English became the official language in Scotland in 1609, in 2018 there were still 50,000 Gaelic speakers. 


\begin{tabular}{|c|c|c|c|c|c|}
\hline $\begin{array}{c}\text { TAB } \\
- \\
\text { LET }\end{array}$ & $\begin{array}{l}\text { OWNER / } \\
\text { WRITER }\end{array}$ & $\begin{array}{l}\text { TEXT OF } \\
\text { TABLET }\end{array}$ & $\begin{array}{l}\text { COLO- } \\
\text { PHON }\end{array}$ & TIME OF WRITING & $\begin{array}{l}\text { PLACE OF } \\
\text { WRITING }\end{array}$ \\
\hline 1 & Not stated & $1: 1-1: 31$ & $2: 1-2: 4 a$ & $\begin{array}{l}\text { 'made at the time when the Lord } \\
\text { God revealed the knowledge of } \\
\text { the creation.' }\end{array}$ & \\
\hline 2 & Not stated & $2: 4 b-4: 26 a$ & $4: 26 \mathrm{~b}-5: 1 \mathrm{a}$ & $\begin{array}{l}\text { 'at that time men began to call on } \\
\text { the name of the LORD.' }\end{array}$ & \\
\hline 3 & Noah & $5: 1 b-6: 7$ & $6: 8-9 \mathrm{a}$ & (Self-evidently) before the flood. & \\
\hline 4 & $\begin{array}{l}\text { The sons of } \\
\text { Noah }\end{array}$ & $6: 9 b-9: 27$ & $9: 28-10: 1 \mathrm{a}$ & 'Noah ... then he died.' & \\
\hline 5 & Shem & $10: 1 b-11: 9$ & $11: 10$ & 'two years after the flood.' & \\
\hline 6 & Terah & $11: 11-11: 25$ & $11: 26,27 \mathrm{a}$ & $\begin{array}{l}\text { 'after Terah had lived } 70 \text { years,' } \\
\text { that is, before leaving Ur. }\end{array}$ & \\
\hline 7 & Ishmael & $11: 27 b-25: 10$ & $25: 11,12$ & 'after Abraham's death.' & \\
\hline 8 & Isaac & $25: 13-16$ & $25: 17-19 a$ & 'Ishmael ... died.' & \\
\hline 9 & Esau (1) & $25: 19 b-35: 26$ & $35: 27-36: 1$ & "Isaac ... died." & $\begin{array}{l}\text { 'Isaac [lived] in } \\
\text { Mamre, near } \\
\text { Kiriath Arba'' }\end{array}$ \\
\hline 10 & Esau (2) & $36: 2-7$ & $36: 8,9$ & $\begin{array}{l}\text { 'Esau .... in the hill country of } \\
\text { Seir.' }\end{array}$ & $\begin{array}{l}\text { 'in the hill } \\
\text { country of Seir.' }\end{array}$ \\
\hline \multirow[t]{2}{*}{11} & Jacob & $36: 10-42 a$ & $\begin{array}{l}36: 43 \mathrm{~b}- \\
37: 2 \mathrm{a}\end{array}$ & $\begin{array}{l}\text { 'Jacob lived .... in Canaan,' that } \\
\text { is, before moving to Egypt. }\end{array}$ & $\begin{array}{l}\text { 'Jacob lived in ... } \\
\text { Canaan.' }\end{array}$ \\
\hline & \multicolumn{5}{|c|}{$\begin{array}{l}\text { TABLE 1. } \\
\text { The eleven toledoth showing } \\
\text { the text and colophon references for each tablet, } \\
\text { the owner / writer, } \\
\text { and the time and place of writing. }\end{array}$} \\
\hline
\end{tabular}

Internal evidence

\section{a. Each named person could have written the section preceding his name}

Genesis Chapters 1 to 37 is divided into sections by the toledoth passages (TABLE 1). As argued below (§6.3) we take them as cuneiform-style colophons - a verse or verses concluding a section.

Suppose the person named in the toledoth (' $\mathrm{X}$ ' for short) is the author or owner responsible for the record. Inspection of the text shows that everything in the section preceding X's name could have been written by him $\$$. He would have known the people and personally been a part of the events, or he could have obtained the information from a known reliable source.

Before a momentous event with unforeseeable consequences the head of the clan would naturally bring the family tablets up to date. Thus, Noah compiled TABLET 3 just before the Flood, Terah added TABLET 6 before leaving Ur (commentators have long wondered why the insignificant Terah has an account $\$$ ) and Jacob finalised TABLET 11 shortly before the clan moved to Egypt.

\section{b. The death of the named person is recorded in the next tablet}

A historian writing ancient history records the death of his subjects at the end of their life, but the writers of these tablets didn't $\$$. Each history ceases before the death of X, and X's death is recorded in the next tablet. For example, Noah's toledoth comes just before the Flood at Gen. 6:9a, and his death is recorded by his sons at Gen. 9:28; Terah's toledoth comes at Gen. 11:27a, and his death is noted in the next section at 11:32. The obvious explanation is that each writer $\mathrm{X}$ was contemporary with his subject matter. 


\section{c. Many of the Genesis stories are first-person or eye-witness accounts}

For example, Abraham looking down towards Sodom with Lot, and later watching its destruction; the conversations of Abraham with Sarah, Sarah with the three visitors, Isaac with Jacob and Esau, and Jacob with his wives and his father-in-law.

\subsection{Archaeological and linguistic evidence}

\section{a. Genesis 4:22-5:1 - the 'written account'}

has been discussed in $\$ 3.4$ above.

\section{b. Genesis 4:17-5:32 — the Babylonian King Lists}

David Rohl has established links between the Sumerian King List, the Assyrian King List (AKL), the Genealogy of the Hammurabi Dynasty (GHD), and the genealogies in Genesis 4 and 5. He has derived related consonantal roots and names roughly in the same order as the names in GHD and AKL for at least seven of the names in Genesis 4 and 5, including Adam and Noah. He asks 'Is this simply a matter of extraordinary coincidence? ... Or did they all really originate from a single source document such as an early Sumerian tablet?' $\$ 32$

\section{c. Genesis 10 - Ethno-geographical information}

Given the many cuneiform references to the flow of trade c. 2000-1800 BC in the area outlined by this chapter 'It would not be unreasonable to assume that this information could have been known to Abraham himself'. ${ }^{33}$

\section{d. Genesis 10:19 - Sodom and Gomorrah}

The mention of of these cities as geographical markers suggests the 'account of Shem' (TABLET 5) must have been written before their destruction c. 1900-1700 BC $\$$

\section{e. Genesis 11:3 - the Tower of Babel}

Kiln-fired brick was used by the Sumerians from around 3100-3000 BC; it was expensive and only employed for important buildings. ${ }^{34}$ The accurate mention with hint of a discussion of the building materials for the project, points to the personal knowledge of a local and contemporary writer $\$$.

\section{f. Genesis 16:2 - Sarah and Hagar}

'The way in which the childless wife Sarah gave her Egyptian slave Hagar to her husband Abraham as a concubine (Gen. 16:2) ... was in full accord with the prevailing local customs;' 35 as in the Code of Hammurabi. ${ }^{36}$

\section{g. Accurate incidental cultural details}

- 'The price of twenty shekels of silver paid for Joseph in Genesis 37:28 is the correct average price for a slave in about the eighteenth century BC. ${ }^{37}$

- Place names from Abraham's travels in Palestine, which would have been unfamiliar to readers in Egypt several generations later, were updated by Moses in TABLET 7. For example, Gen. $14: 2,3,7,8,15,17 ; 23: 2$ 'Sarah died in Kiriath Arba (that is, Hebron) in the land of Canaan'.

\footnotetext{
Rohl, 193-197.

D. J. Wiseman, ‘Genesis 10: Some Archaeological Considerations', Faith and Thought 87 (1955) 14-24.

Paul H. Seely, 'The Date of the Tower of Babel and some Theological Implications', WTJ (2001):15-38, esp. 17.

Harrison, 109.

36 The Code of Hammurabi, King of Babylon, tr. R. F. Harper (Chicago: University of Chicago Press, 1904): law 146.

37 K.A. Kitchen, Ancient Orient and Old Testament (London: Inter-Varsity Press, 1966): 53.
} 
- Kiln-fired bricks were not known in Egypt, where important buildings were built of hewn stone, so Moses added this translator's gloss: 'They used brick for stone, and bitumen for mortar' (Gen. 11:3).

\section{h. Traces of Sumerian in the English bible}

Texts translated into another language often contain traces of the idioms and structure of the original. For example, the AV in 1 Kgs. 21:21 gives a literal translation into English (bowdlerised in modern versions) of the Hebrew idiom mastin beqir 'pisseth against the wall' meaning male.

The oldest Hebrew manuscript dates from c. 1000 BC. Nothing is known of the earlier history of Hebrew; but similarities of vocabulary and structure with the thousand-years-older Akkadian (FIGURE 5) suggest that both belong to the same (Semitic) language group and therefore that Hebrew may have developed from or been influenced by Akkadian.

If the original text was in Sumerian, it is not surprising that some lexical traces of Sumerian, passed via the Hebrew text and Tyndale, are found in the English bible. Why did Tyndale use the phrase the heavens and the earth for the universe rather than sky and land or some other phrase? The phrase in the day that (= when) is not found in Shakespeare so presumably was not then standard English; so why did he use it several times? The following are comparisons of exact citations from reference works with the AV:

- Genesis $1: 1 ; 2: 1,4 \mathrm{a}$ 'The heavens and the earth'. earth.' 38

'[The Sumerian] term for universe was an-ki, a compound word meaning heaven-

- Genesis 1:24, 6:7 'animals of the earth'.

'nín-ki: vermin; beasts ('things' + 'ground').' 39

- Genesis 1:30; 2:7 'Having the breath of life'.

'zi-ñál(-la): = living being: ("breath" + "to be available").' 40

- Genesis $2: 4,17 ; 3: 5 ; 5: 1,2$ 'in the day that ...'.

Sumerian lacks a distinct word class of adverbs. The Sumerian equivalent of an English time adverb is a noun phrase which can have a temporal meaning. Thus for when it uses $\mathrm{u}_{4}$-ba = then (lit. "on this day"), ${ }^{41}$ and a Sumerian grammatical construction has passed into the AV. (This technical citation is simplified).

- Genesis 3:19 'To dust you shall return'.

"sahar(-da)... gi 4 : to turn into dust; euphemism for "to die" ("dust" + "to turn, return"). '42

- Genesis 7:11 'the fountains of the great deep'.

'idim: n., spring, underground water; ... (ída, 'river', + mú, 'to sprout, appear').' ${ }^{43}$

- Genesis 11:3 'Burn them thoroughly' - an odd expression. Bricks were not made in kilns in Egypt in the time of Moses; the Hebrew slaves made them from clay mixed with straw (Exod. $5: 7)$.

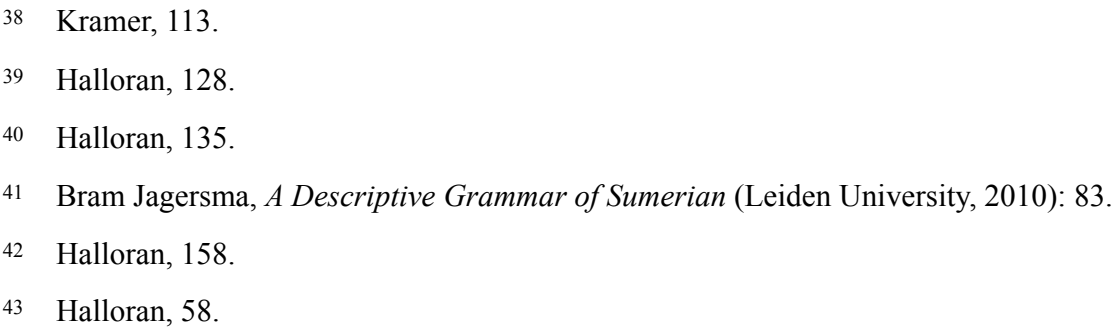


Sumerian sig $_{4}$-al-ur 5 -rà = 'kiln-burnt brick'; from

$\operatorname{sig}_{4}=$ 'sun-dried brick';

al is a prefix;

$u r_{5}=$ 'heart';

$r \grave{a}=$ 'blaze.'44

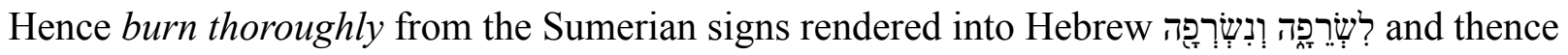
into the English Bible.

- Genesis 11:7, 8 'confound their language'.

'eme-gilim-ma: confused speech ('tongue' + 'to be twisted, tangled' + nominative). ${ }^{45}$

- Genesis 24:67 'Isaac was comforted [that is, by his wife].'

'niñ-ur 5 -sa6-sa6: sweetness; (sexual) happiness ('thing' + ur ${ }_{5} \ldots s a_{6}$, 'to feel comfortable').' 46

- Genesis 31:10 'striped, speckled or spotted'.

'gùnu, gùn:... adj., striped; speckled, spotted.' ${ }^{7}$

FIGURE 5 shows that Babel is a transliteration from Akkadian not Sumerian, a trace of Akkadian in Genesis in the English bible; supporting the suggestion ( $\$ 3.5)$ that the Genesis tablets may have been written in or translated into Akkadian.

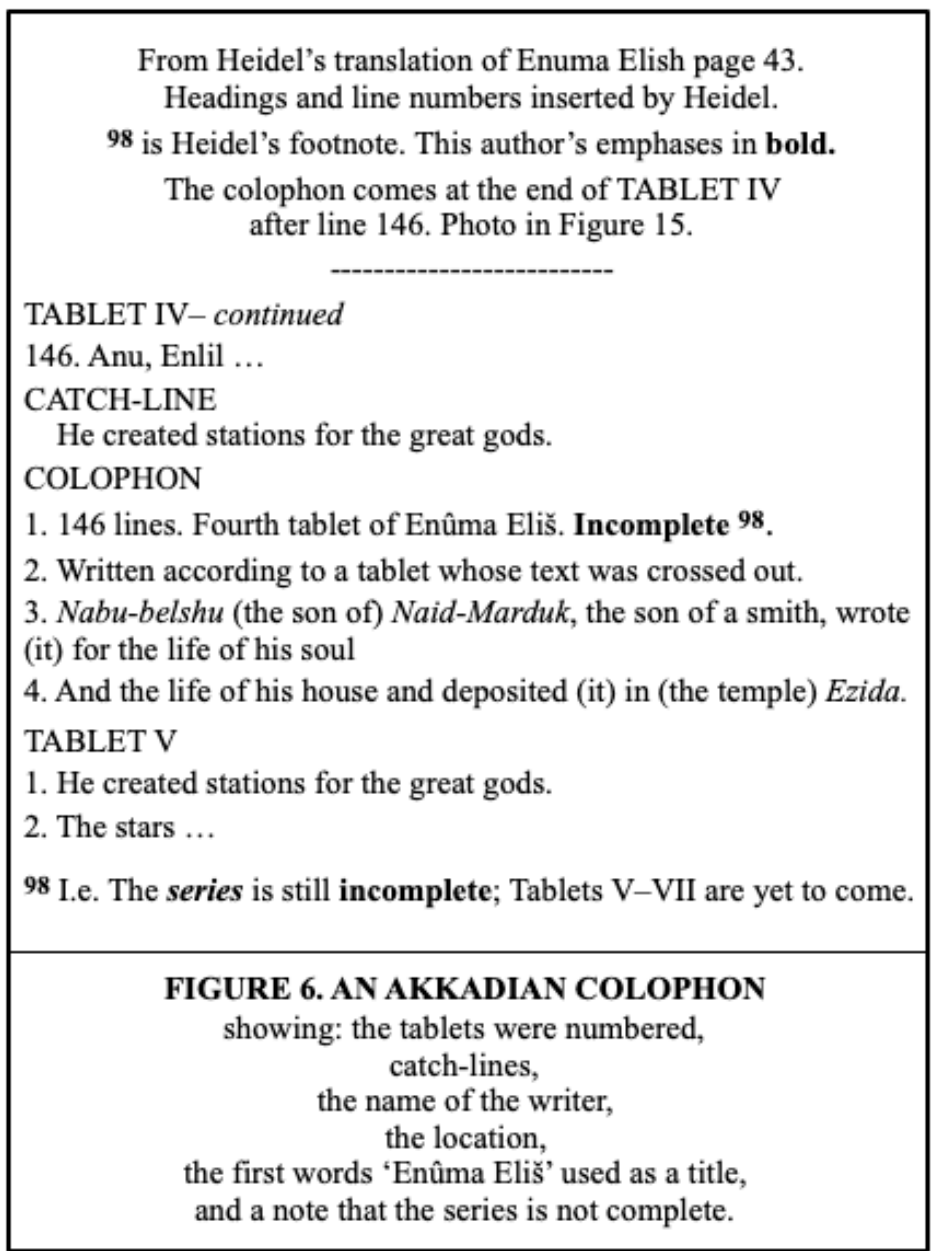

Gen 1:1 'God created the heavens and the earth.'

Gen 2:4 'the heavens and the earth when they were created.'

Gen 2:4 'when they were created.'

Gen 5:2 'when they were created.'

Gen 6:8 'Noah found favour in the eyes of the Lord.'

Gen 6:9b 'Noah was a righteous man.'

Gen 6:10 'Noah had three sons.'

Gen 6:10 'Shem, Ham and Japheth.'

Gen 10:1 'Shem, Ham and Japheth.'

Gen 10:1 'Noah's sons' 'after the flood.'

Gen 11:10 'after the flood.'

Gen 11:26 'Abram, Nahor and Haran.'

Gen 11:27 'Abram, Nahor and Haran.'

Gen 25:12 'Abraham's son Ishmael.'

Gen 25:19a 'Abraham's son Isaac.'

Gen 25:19b 'Abraham became the father of Isaac.'

Gen 36:1 '(that is,) Edom.'

Gen 36:8 '(that is,) Edom.'

Gen 36:9 'Esau, the father of the Edomites.'

Gen 36:43 'Esau, the father of the Edomites.'

\section{FIGURE 7.}

Repeated phrases in cuneiform style serving as titles, inclusiones, link- and catch-phrases.

\footnotetext{
44 Halloran, 137, 26, 6, 7, 19.

45 Halloran, 87.

46 Halloran, 129.

47 Halloran, 37.
} 


\section{Evidence that the toledoth are Sumerian or Akkadian Colophons}

Sumerian and Akkadian scribes frequently appended a colophon to a tablet or series of tablets. We now examine the similarities between toledoth and cuneiform colophons.

\subsection{The literary usage of cuneiform colophons}

FIGURE 6 shows the colophon at the end of TABLET IV of the epic Babylonian Story of Creation, and indicates the features of a typical cuneiform colophon. ${ }^{48} \mathrm{We}$, like the Akkadians, call the story by its first words, Enuma Elish. FIGURE 15 shows a photo of part of this tablet and the Akkadian text of Line 1 of the colophon.

Erle Leichty wrote the definitive review of the features of cuneiform colophons, ${ }^{49}$ which included:

- 'Tablets which are part of a series are numbered consecutively like chapters in a book in order to denote their sequence in the composition.'

- Catch-lines were repeated at the end of one tablet and the beginning of the next.

- The writer or owner and the place and date of writing were given, and

- 'the name of the series is taken from the first line of the first tablet of the series.'

- "Very often the number of the tablet and name of the series are followed by AL.TIL "finished", or NU AL.TIL "not finished" [in FIGURES 15 and 16 "incomplete"] in order to indicate whether the tablet is the final tablet in the series.'

\subsection{The toledoth have many features of cuneiform colophons}

Inspection of the toledoth passages shows literary features - titles, names, catch-lines, dates and places - similar to cuneiform colophons:

- Each toledoth summarises or otherwise marks the end of a section.

- All except the first mention a person in connection with toledoth - the writer or owner X always given in Sumerian colophons. (In the second, X's line is the subject of the writing).

- a dozen repeated phrases (FIGURE 7), either catch-phrases connecting the end of one tablet with the start of the next, TABLETS $1-2,3-4,4-5,6-7$, and $8-9$,

- or serving as a subject or title repeated at the end of the section, forming an inclusio, in TABLETS 1, 2, 4, 5, 8, 10, and 11 (4 occurrences).

- All the toledoth except the first have an indication of the date (allowing one to be self-evident) at which the tablet was written;

- and the last three toledoth indicate the location at which the tablet was written.

\section{3 'Dormant anomalies' disappear in the light of Sumerian usage}

- Genesis 11:26 'Terah lived 70 years' $\$$, when understood as dating the writing of the tablet, removes the apparent discrepancy with Gen. 12:4.50

- Genesis 37:1 'Jacob lived in the land where his father had stayed, the land of Canaan' is seen to serve a useful purpose $\$$ when understood as giving the place and time of writing of the tablet, in Canaan before they left for Egypt.

- The duplicate phrases $\$$ (FIGURE 7), usually supposed to be the work of careless editors, all have a purpose when understood as inclusiones or catch-phrases.

48 Alexander Heidel, The Babylonian Genesis: the Story of the Creation (Chicago: University of Chicago Press, 1963 ): 43.

49 Erle Leichty, 'The Colophon', in R. M. Adams, ed., From the Workshop of the Chicago Assyrian Dictionary: Studies Presented to A. Leo Oppenheim (Chicago: University of Chicago Press, 1964): 147-154.

$50 \quad N D G B, 51$. 
If Genesis 5 was originally written in Sumerian a thousand years before Moses, errors in transmission are a reasonable possibility. PART 2 offers a detailed explanation.

\section{$5.5 \quad$ The internal evidence}

If all the toledoth are conclusions to a section, these two sets of observations are consistent: (1) the events preceding each of the nine persons $X$ fall in his lifetime, and (2) each of their deaths comes in the next section. As they would not be consistent if some or all of them were headings, we may reasonably conclude that the toledoth are colophons, each concluding a section of text.

(There are a few variations: Gen. 1:1-2:4 starts at the creation and has no name at the end; $5: 1$ states it is the account of ' $X$ 's line', not of $X$; in Gen. 36:10-43c we have three tablets from Esau's now distant family, presumably copied in by Jacob, each bracketed by an inclusio; but these do not affect the argument).

\section{$5.6 \quad$ The evidence assembled}

The shared cuneiform literary features, the internal evidence that the toledoth are conclusions to a passage and the indications of contemporary writing, taken together indicate that a Genesis toledoth identifies an original Sumerian or Akkadian colophon, and therefore that Genesis 1:1-37.2a was very likely written in cuneiform.

Further confirmation: the reason why no more toledoth are found after Gen. 37:2a is that Jacob and his family removed to Egypt, where writing was on papyrus and clay tablets were not used $\$$

\section{Academic Opinion on Colophons}

The thesis of this paper is not new. In 1936 P. J. Wiseman published a small book claiming that archaeological evidence led to the conclusion that the clan of Abraham wrote their histories in cuneiform script on clay tablets, at or not long after the time of the events recorded, and that Moses translated and compiled these sources to produce the Hebrew text of Genesis.

\subsection{Academic support for P. J. Wiseman}

Professor Donald J. Wiseman ${ }^{51}$ edited and reprinted his father's book in 1977,52 and published a detailed review of the evidence, supporting the cuneiform origin of Genesis and the Six Days interpretation in 1991.53

R. K. Harrison considered the archaeological evidence in detail and found it convincing. 54 Dale S. de Witt supported and built on P. J. Wiseman.55 Pierre Duranleau discusses fully the pros and cons of toledoth and colophons, supporting Wiseman. 56 Peter Rüst says 'the text of Genesis 136 contains remarkable tell-tale indications of having originated as cuneiform records' ${ }^{57}$ The

\footnotetext{
51 P. J. Wiseman did not hold any academic post. His son, Donald. J. Wiseman, was the eminent evangelical Assyriologist.

52 P. J. Wiseman, Clues to Creation in Genesis, ed. Donald J. Wiseman (London: Marshall, Morgan \& Scott, 1977); and Ancient Records and the Structure of Genesis: A Case for Literary Unity, ed. Donald J. Wiseman (London: Nelson, 1985).

53 Donald J. Wiseman, 'Creation Time ...': 25-34.

54 Harrison, esp. 544-553.

55 Dale De Witt, 'The Generations of Genesis', EvQ 48 (1976): 196-211.

56 Pierre Duranleau, 'The Toledoth and the Mesopotamian Colophon, in The Origins and Transmission of the Book of Genesis, Wiseman's Theory and its Impact on the Biblical Scholars (Canada: Montreal, Faculté de Théologie Évangélique affiliée à l'Université Acadia, 2005).

57 Peter Rüst, ‘Early Humans, Adam, and Inspiration', PSCF 59.3 (2007): 185.
} 
Roman Catholic scholar Damien Mackey supports Wiseman on colophons. ${ }^{58}$ David Rohl concludes, very significantly because independently of Wiseman, that 'some of the original Genesis sources ... were Sumerian'. 59

\subsection{Academia against Wiseman}

We now consider together the objections in three textbooks from conservative American theological seminaries and the Tyndale Commentary on Genesis. ${ }^{60616263}$ They all raise the same objections.

\section{a. The colophons are inconsistent with one another}

It is argued that three or four of the colophons would read better as headings rather than endings of a section; for example, 10:1a could be the heading of the genealogy of Noah's sons, 11:10 of Shem down to Terah and 25:12 of Ishmael's sons.

But the internal coherence when all the colophons are read as conclusions, evidenced in $\$ 4.1$, surely outweighs an English-speaking scholar's opinion of what a scribe writing four or five thousand years ago in a language isolate that the scholar can't read, might think would read better.

\section{b. The colophons are not as clearly defined as claimed}

I admit that the start and finish of some of the colophons are not as certain as implied by the tidy TABLE 1 and are open to debate; some sympathetic imagination is required.

\section{c. Moses couldn't read cuneiform}

Although 'Akkadian, written in cuneiform, was the lingua franca of the entire Near East', ${ }^{64}$ these scholars suppose that the well-educated Moses wouldn't have been able to read cuneiform tablets, or find a scribe to translate them. Really?

\section{d. Quarrelling brothers wouldn't cooperate}

It is suggested that the friction between Isaac and Ishmael and between Jacob and Esau would have made their cooperation over the family history tablets unlikely.

However, when a clan has recorded their family history for many generations, a current siblings' quarrel will not outweigh the duty of the eldest son to keep the records up to date.

Ishmael was responsible for the record of Abraham's life and times. (He might have deputed Isaac to see about it). When he predeceased Isaac, Isaac took over the archive and in his tablet recorded Ishmael's death and the names of his sons.

As the Genesis record states that Esau and Jacob were eventually reconciled and together buried their father (Gen. 35:29), the suggestion that they would not have cooperated over the family tablets is somewhat unconvincing. Esau was the elder, and recorded the life of their father Isaac; when he distanced himself from the clan Jacob took over the records.

There is no evidence that in either case the usual procedure was not followed.

\footnotetext{
58 Damien F. Mackey, 'Toledôt of Genesis Part One: Colophon Key to the Structure of Genesis' (Australian Marian Academy of the Immaculate Conception).

59 Rohl, 223.

60 Allen Ross, 'Genesis' in John F. Walvoord et al., The Bible Knowledge Commentary: Old Testament (Colorado Springs: Cook, 1985): $2-23$.

61 Victor P. Hamilton, The Book of Genesis: Chapters 1-17 (Grand Rapids: Eerdmans, 1990): 2-9; 37-38.

62 Herbert M. Wolf, An Introduction to the Old Testament Pentateuch (Chicago: Moody, 1991): 65-66.

63 F. Derek Kidner, Genesis (London: Tyndale, 1967): 23-24.

64 Irving Finkel and Jonathan Taylor, Cuneiform (London: British Museum 2019): 66.
} 


\section{e. The 'written account' is impossible}

Genesis 5:1 is supposed to imply, if 'This is the written account of Adam's family line' is taken seriously, that writing is as old as man himself. But surely it only implies that writing is as old as urban civilisation, which is archaeologically correct.

\section{f. Unity of theme or purpose}

Alternative explanations to colophons are suggested on the basis of the unity or plan of the book, for example, structural design (Hamilton), the development and geographical expansion of the narrative (Ross), Moses's excellent qualifications for authorship (Wolf), or function and authorial intent (Walton), ${ }^{65}$ but they do not explain why the toledoth are there at all $\$$.

The inconsistencies argued against colophons argue equally against a single author or editor; and no known ancient or modern historian puts the death of each main character in the chapter after his life and times $\$$

\subsection{Conclusion of the colophon debate}

Compared with the several lines of hard evidence in $\S 5$ these objections are weak and far from conclusive. Inconsistencies in a compilation of materials written and translated by different authors in different languages over hundreds of years carry little weight. All the toledoth have some of Leichty's characteristics of colophons, and they can consistently all be read as conclusions to a section of text.

'If it looks like a dog and barks like a dog, it probably is a dog.'

\section{Source Criticism of the Cuneiform Text}

The perspective of contemporary writing and Sumerian or Akkadian original documents suggests some alternative answers to the traditional critical questions.

\subsection{The Sumerian 'trained scribe'}

Hundreds of clay tablets have been discovered from the schools in which Sumerian and Akkadian scribes were instructed in their highly skilled profession. From them we learn that

Intellectually immobilized by his sterile and static attitude to the history of man, the Sumerian man of letters could at best become an archivist rather than a historian, a chronicler and analyst rather than an interpreter and expositor of historical truths; 66 and,

The principal concern of the properly trained Mesopotamian intellectual scribe was to preserve and transmit inherited lore, with the inbuilt rider that the older a document the better. ${ }^{67}$

His job was not to ascertain the course of historical events but to preserve such information as was available.

\section{a. The 'trained scribe' - variant accounts}

Noah, instructing a scribe to update the family records before the coming flood, would have given him TABLETS 1 and 2 passed down from many years earlier, including our Gen. 4:17-5:1a. The family have in their possession a tablet with another list of ancestors (Gen. 5:1b-31), so following

\footnotetext{
65 John H. Walton, The Lost World of Genesis 1 - Ancient Cosmology and the Origins Debate (Downers Grove: InterVarsity Press, 2015): 51.

66 Kramer, 34.

67 Irving and Taylor, 53.
} 
the rule of his profession, the 'trained scribe' copied both into the new TABLET 3 . In its time that was a sensible procedure and a cultural norm.

The three similar stories of Abraham / Isaac and wife in Egypt could be from three more-orless contemporary sources such as servants or family members, and treated the same way.

\section{b. The 'trained scribe' - the Flood narrative}

Being an educated and sensible fellow, our scribe knows that it would be impossible to get two of every type of animal and bird into even an unusually large boat.

So he retains the actual words (as required in modern academia) of his sources - who may not have been eyewitnesses anyway - knowing they are impossible if taken literally and sometimes inconsistent with each other, and incorporates them in a literary framework such as Wenham's palistrophe, ${ }^{68}$ assuming his readers are also educated and sensible.

The early Sumerians built river-going ships so our scribe knows that a heavily loaded boat 150 yards long made of wood and reeds would break its back on the smallest wave, ${ }^{69}$ so all the animals obviously means a representative selection. He assumes his readers will know that the ordinary people don't know how to specify linear measurements, so a large, to us seemingly an exact number, may mean little more than ginormous or awesome. ${ }^{70}$

The only recent cuneiform expert who has written about the ark is Irving Finkel. On the basis of one clay tablet he claims the ark was a sort of large coracle. ${ }^{71}$

\section{c. The 'trained scribe' - the local flood and the 'one language'}

The scientific evidence against a universal flood and against one world language c. $3000 \mathrm{BC}$ is incontrovertible. The archaeological evidence is of a number of inundations in the area, and that Sumerian was the local language, but the nature of the linguistic changes, which was the biblical flood and its date, and how far it extended, are at present undetermined. ${ }^{72}$

The 'trained scribe' knows that illiterate people are not accustomed to precise statement, so in regard to the extent of the flood, the whole world means little more than as far as the eye can see; ${ }^{73}$ and although as a scribe he would have known of other languages, he recorded his source's words 'The whole world had one language and a common speech' (Gen. 11:1).

An influx of Akkadian-speakers into the Sumerian-speaking city could have caused the linguistic confusion - experienced today by every student of cuneiform — that disrupted the building of the Tower of Babel.

Paul H. Seely, building on Calvin, justifies the above approach to the text as accommodation of Scripture in a pre-scientific culture. 'Scripture is accommodated ... to the limited geographical and anthropological knowledge available at the time.' 74

A cynical reader might comment that the 'trained scribe' coupled with Calvin's accommodation is a conservative catch-all equivalent of half-a-dozen hypothetical redactors.

\footnotetext{
68 Wenham, VT (1978): 336-348.

69 Bernard Ramm, The Christian View of Science and Scripture (London: Paternoster, 1964):156. His attempt to justify the biblical dimensions of the ark is only plausible to those with no knowledge of engineering and materials science.

70 English colloquialisms for extremely large.

71 Irving Finkel, The Ark Before Noah: Decoding the Story of the Flood (London: Hodder \& Stoughton, 2014).

72 Seely, 25-28, and many articles in the literature.

73 Ramm, 163, agrees with this local reporter interpretation of the extent of the flood.

74 Seely, 32-38.
} 


\section{d. Another Sumerian literary custom}

The Aratta epic (c. 2100 BC, FIGURE 7A) in this fascinating passage credits the invention of writing to Enmerkar, indicating that in Genesis 4:20-22 the attribution of livestock farming, musical instruments, and metal-working to named ancestors was in accordance with a Sumerian literary custom.

His speech was substantial, and its contents extensive. The messenger, whose mouth was heavy, was not able to repeat it. Because the messenger, whose mouth was tired, was not able to repeat it, the lord of Kulaba [Enmerkar] patted some clay and wrote the message as if on a tablet. Formerly, the writing of messages on clay was not established. Now, under that sun and on that day, it was indeed so. The lord of Kulaba inscribed the message like a tablet. It was just like that. 75

\subsection{Moses, the underrated historian}

The Judaeo-Christian research ethic was foreshadowed

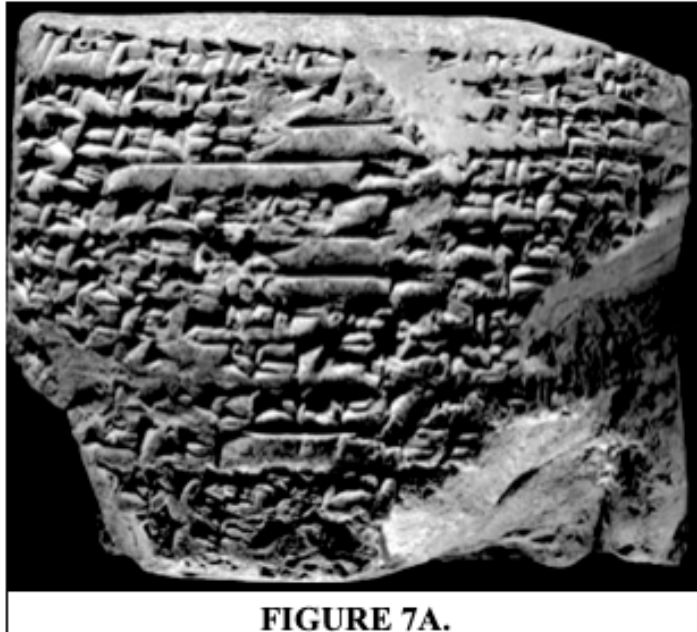

A fragment of the Aratta tablet (not the part translated opposite), c. 1900-1600 BC. $6.2 \times 5.0 \mathrm{~cm}$. Ashmolean Museum 462298 .

by Moses. The duplicate catch-lines and accounts of the same event are a normal part of Sumerian and Akkadian literary usage. In accurately translating and giving the provenance of his sources 'the account of $\mathrm{X}$ ' - and not editing out these apparent redundancies $\boldsymbol{\phi}$, Moses was paralleling modern academic practice for the treatment of ancient records, and incidentally pointing to his reliability as a historian.

\section{Summary of the Arguments for the Paradigm Shift}

Ockham's Razor argues strongly that a cuneiform origin is both simpler, ${ }^{76}$ and more adequate in explaining features and resolving anomalies, than the Documentary Hypothesis.

\subsection{JEDP ignores significant archaeological and literary evidence}

Namely, the invention and development of Sumerian writing and the accurate cultural background.

\subsection{JEDP lacks any positive archaeological evidence}

'None of the alleged documents has ever been found.' 77 The theory that the use of Jahweh and Elohim distinguishes two documents $\mathrm{J}$ and $\mathrm{E}$ is devoid of archaeological support $\mathbf{\$}$; Akkadian literature frequently uses more than one name of a god in one tablet.

Hermann Hunger translated 563 colophons, of which some forty (the oldest ones) act as controls for the hypothesis that the toledoth in Genesis are cuneiform colophons; but the paradigm theory that JEDP is a compilation of ANE documents lacks any such extra-biblical controls $\mathbf{\phi}$

This longstanding lack of archaeological evidence undermines the foundation of the traditional critical analysis of Genesis. Although in recent decades academic support for JEDP has fallen off, nothing has been on offer to take its place. This paper puts forward an evidence-based alternative.

\footnotetext{
75 Enmerkar and the Lord of Aratta: <https://etcsl.orinst.ox.ac.uk/section1/tr1823.htm, lines 500-509.

76 See the complex diagram of JEDP in Wikipedia 'The Documentary Hypothesis'.

77 For example, Wolf, 67.
} 
(1) Why every record stops in the lifetime of the named person ' $X$ ', (2) whose death is recorded in the next tablet, (3) the written account, (4) the redundant phrases and (5) why the toledoth stop at Chapter 37. Several others have been pointed out en passant, and there are more to come.

From within a paradigm the dormant anomalies are seen as isolated facts, like the scattering of dots on a children's puzzle page. Only when you join up the dots does the picture appear. 'The facts are known but they are insulated and unconnected.... The pearls are there but they will not hang together until someone provides the string.' 78

P. J. Wiseman provided the string, one simple hypothesis that connects the dots and integrates the anomalies into a complete and realistic picture: the text of Gen. 1:1-37:2a was written in cuneiform on clay tablets: 1:1-5:1a not long after the invention of writing, and 5:1b-37:2a at about the time of the events recorded.

After a trickle of the new ideas, paradigm shifts tend to occur suddenly - no-one notices that the water is gradually eroding the foundations, then suddenly the building collapses.

\subsection{Summary of the evidence that Genesis 1:1-37:2a has a cuneiform origin}

- Writing, of the Sumerian language, was invented c. 3200 BC.

- Genesis 5:1 states that it concludes a written account.

- The patriarchs lived in Sumer and were literate in Sumerian and/or Akkadian.

- Internal evidence points to a compilation of contemporary writings.

- Many details in Genesis are authentic to the time and place of the events described.

- Cuneiform writings on clay tablets have recognisable features, in particular, colophons.

- Every toledoth has features of cuneiform colophons.

- Toledoth are not found after the account of Jacob's removal to Egypt.

- Creation stories and other religious writings are a familiar genre of Sumerian literature.

- There are similarities in the names and order between the cuneiform King Lists and the genealogies in Genesis.

- There are linguistic traces of Sumerian in the English Bible.

- Dormant anomalies in the current paradigm disappear.

In PART 2, a cuneiform origin

- if the transcription error is accepted, is confirmed; and

- reduces the ages in Genesis 5 to a more likely range.

In PART 3, a cuneiform origin

- provides a more meaningful translation of Gen. 2:1-4;

- clarifies several obscure texts;

- recommends an interpretation of the Six Days that removes all conflict with science.

\section{A Reasonable Conclusion}

'When lines of evidence cohere, to thoughtful minds the truth is near.'

The Sumerian / Akkadian literary features and the accurate cultural details confirmed in the Assyriology journals over a hundred and fifty years are independent facts. What simpler explanation of all these features of Genesis is there than that the patriarchs and their ancestors wrote their family histories in their own language in cuneiform on clay tablets, which were carefully preserved and eventually passed down to Moses, who transcribed them into what we know as the early chapters of Genesis?

78 William Whewell, Philosophy of the Inductive Sciences (1847): 48. 
Contrary to the view that Christians cannot truly be scholars since their work is biased from the outset by their faith, this thesis has relied entirely on archaeological evidence open to proof or disproof, interpreted without any religious presuppositions. In the absence of contrary evidence it is a reasonable and scientific conclusion that the sources of the earlier chapters of Genesis are cuneiform in origin.

Paradigm shifts are never readily accepted by an establishment. Despite being a far worse fit to the observations of the planetary movements, it was a hundred years or more before the complex epicycles of Ptolemy were replaced in the intellectual world by the simple ellipses of Copernicus.

The cuneiform alternative paradigm is a simpler and far better fit to the archaeological and linguistic evidence and the text of Genesis; it has never been disproved, and deserves serious consideration. 


\section{PART 2}

\section{A TRANSCRIPTION ERROR EXPLAINS THE AGES \\ OF THE PATRIARCHS BEFORE THE FLOOD}

$* * * * *$

\section{A New Solution to an Old Problem}

Gordon J. Wenham reviewed the efforts of the many scholars who have played with the ages of the antediluvian patriarchs in the Hebrew text, and the few who attempted some connection with the Babylonian sexagesimal system, and concluded 'no writer has offered an adequate explanation of these figures' ${ }^{79}$ More recently, Carol A. Hill reviewed and rejected explanations based on changes in the earth's rotation or climate, linguistic misunderstandings, or a name standing for a clan or dynasty. 80

If Genesis Chapters 1 to 5 was originally written in Archaic Sumerian a thousand years or more before Moses, errors in transmission are a reasonable possibility. As the explanation of the unlikely ages of the antediluvians, this paper proposes transcription errors caused by reading numbers written on the decimal system hundreds of years earlier, as though they were sexagesimal numbers.
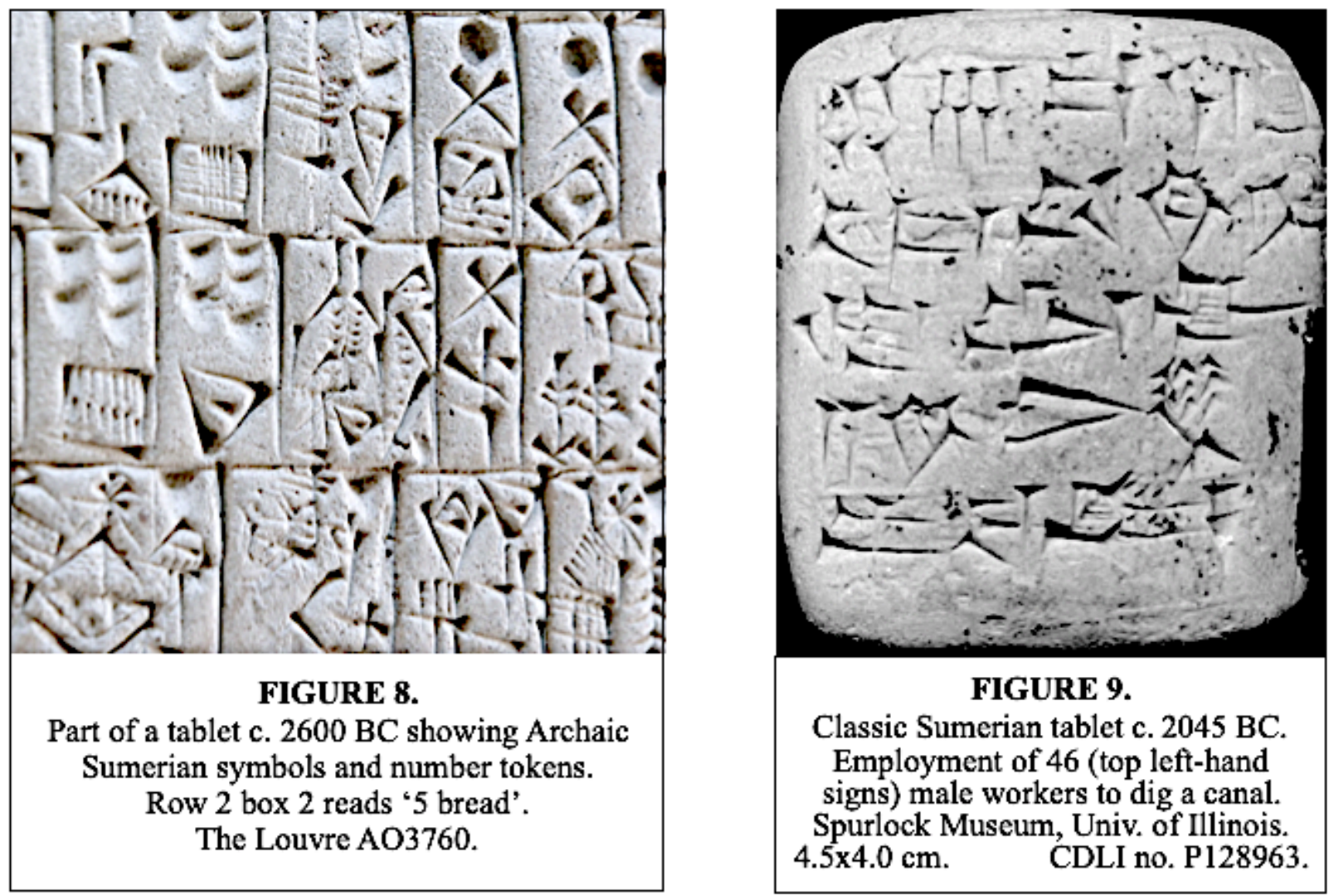

\section{Writing and numbers from Sumerian to Akkadian}

\subsection{Sumerian}

The language of the alluvial plain Between the Rivers was Sumerian. The writing on the tablet in FIGURE 8, a business contract, is Archaic Sumerian. The circular and crescent-shaped signs, (also

\footnotetext{
79 Wenham, 134.

80 Carol A. Hill, PSCF 55.4 (2003): 239-251.
} 
visible in FIGURE 1) which were made by impressing the blunt end of the reed stylus into the soft clay either perpendicularly or obliquely, are number tokens.

Number tokens are simply added up. Different sets of tokens were used for different goods and in different towns and at different times - a translator's nightmare.

Between 2600 and 2000 BC the symbols, including the number tokens, were replaced by cuneiform signs (FIGURES 9, 12 and 13).

\section{2}

Akkadian

Akkadian was the lingua franca of the ANE for two thousand years. Ancient Sumerian tablets were regularly and painstakingly copied and transcribed into Akkadian. They kept the same wedge signs for 1 and 10 (FIGURE 12), and around 2000 BC they introduced the sexagesimal system.

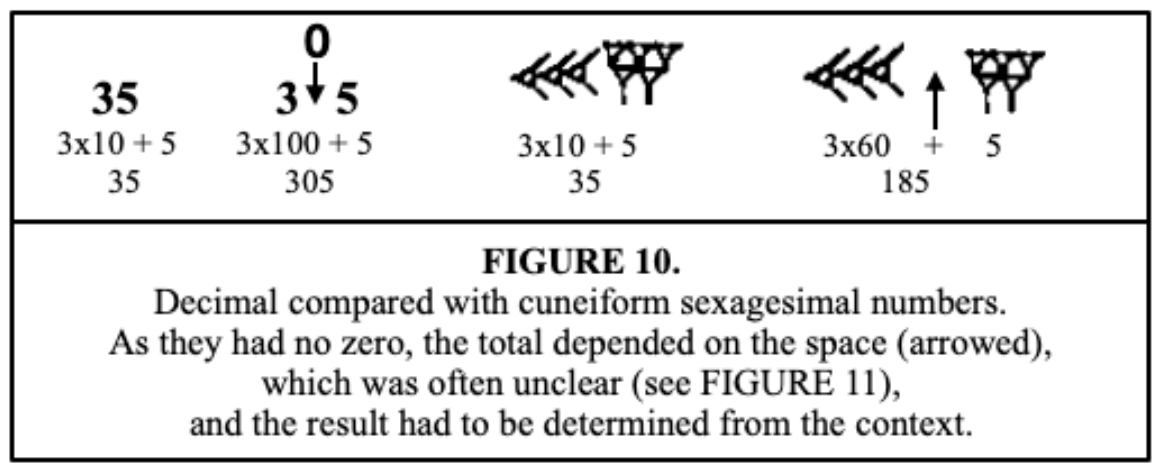

\section{The Akkadian Sexagesimal System}

\subsection{The Sexagesimal Place Value Notation (SPVN) system}

Our arithmetical system uses a decimal PVN. 786 is interpreted as

$$
6+\left(8 \times 10^{1}\right)+\left(7 \times 10^{2}\right)=786 . \quad\left[n^{1=} n\right] .
$$

But on the SPVN system, 786 would be read as

$$
6+\left(8 \times 60^{1}\right)+\left(7 \times 60^{2}\right)=25286 .
$$

The Akkadians did not have a pure base-60 system. To represent the numbers 1 to 59 within each place value, they used ten as a sub-base: the equivalent of our units column was a set of up to nine vertical wedges, with to the left a group of up to five of the angled wedges, called Winkelhaken, taking the possible total up to 59 ; illustrated by ' 35 ' in FIGURE 10 and ' 46 ' in FIGURE 9. Sometimes wedges were used instead of Winkelhaken, as in FIGURE 15 ' $2 \times 60$ '; This allows two possibilities when converting the number tokens to cuneiform signs, for example: ' 21 ' in FIGURE 13.

\subsection{The Akkadians had no zero}

See FIGURE 10. To write three hundred and five we put a zero in the ten's place. But the zero had not been invented, so the Akkadians simply left a space between the two signs. To save space the signs on a clay tablet had to be written as close together as possible, with the result that the spaces between number signs were often unclear or even non-existent, as in FIGURE 11.

\subsection{Misreading a zero space could cause a large error}

When the text has an indeterminate space where we would have a zero, the correct reading can only be ascertained by referring to the context. Thus in FIGURE 10 we have to decide whether there is or is not a space between the Akkadian signs for ' 3 ' and ' 5 '. In a sexagesimal system, the error caused by misjudging a space can be substantial; in FIGURE 10 the space makes the difference between 35 and 185 . 


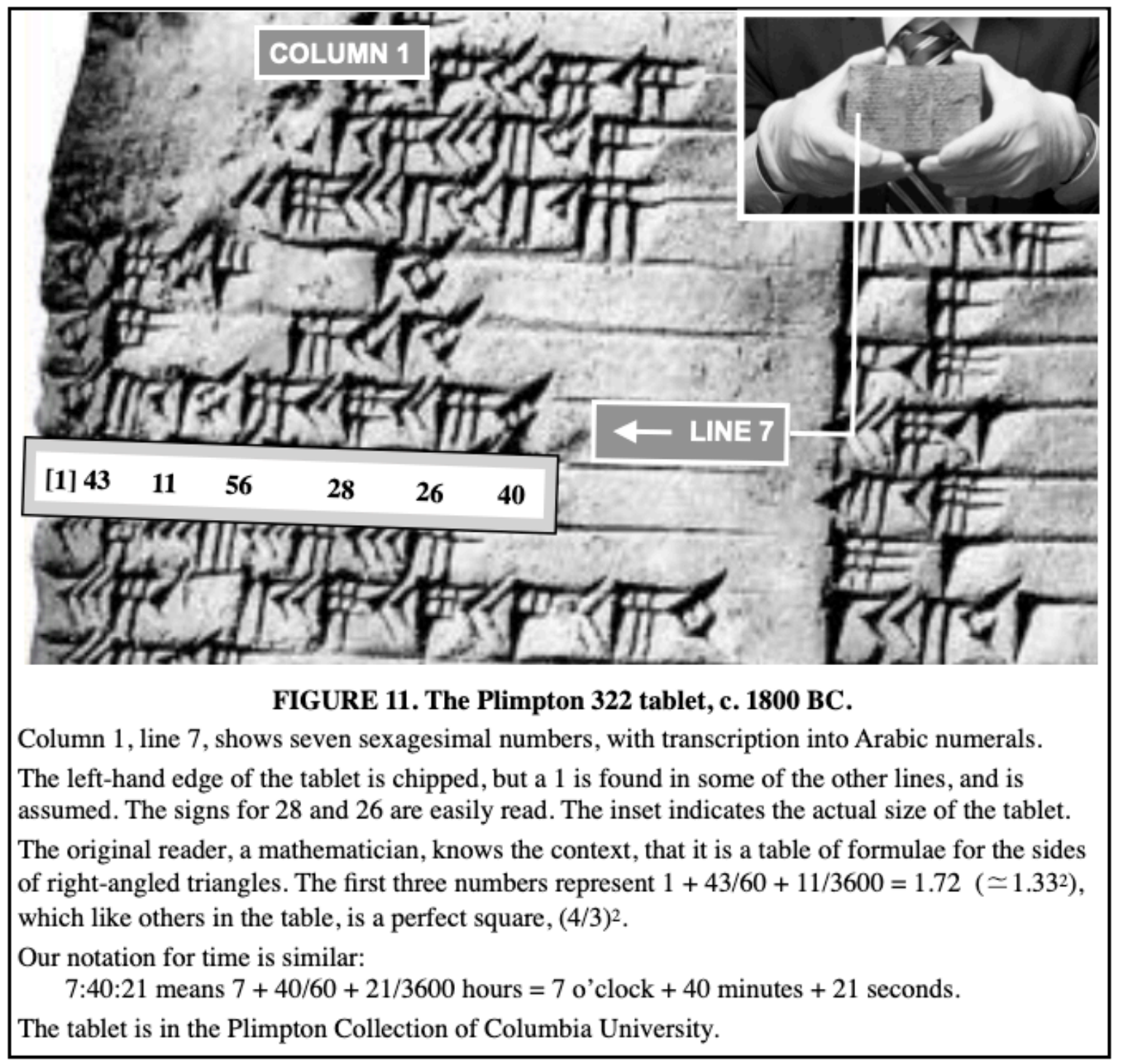

FIGURE 11 enlarges part of the famous tablet PLIMPTON 322, and illustrates that reading the spaces was a real problem; between many of the numbers there is no space at all. Scribal errors were common. Six mistakes have been found in this tablet alone. In one of them the error is the scribe's 'overlooking a medial zero', ${ }^{81}$ (the technical term for, in FIGURE 10, misreading 185 as 35 ). This tablet, with an actual example of mistaken reading of the spaces, proves that medial zero errors are a plausible cause of mistakes in transcription.

\section{The Stages in the Transmission of Noah's Genealogy down to Moses}

Noah's account (Gen. 5:1b-6:9a) incorporating the genealogy with the ages, was written in Archaic Sumerian using number tokens. The ages were later transcribed into cuneiform characters using base ten, and finally read on the sexagesimal system as though they were base sixty. From Noah to Moses is well over fifteen hundred years.

\subsection{The genealogy first written down}

— guesstimate: c. $2800 \mathrm{BC}$

Consider these figures for Adam's life. Suppose the original ages were son born at 21, further life 132, and died at 153 years. These figures are arrived at by inspection and trial and error.

See FIGURES 12 and 13. The figures were originally written using number tokens for 10 and 1 . Adding the number tokens in the first line we have $10+10+1=21$.

\footnotetext{
81 John P. Britton, Christine Proust, and Steve Schneider, 'Plimpton 322: a review and a different perspective', Archive for History of Exact Sciences (2001) 65 (5): 519-566.
} 


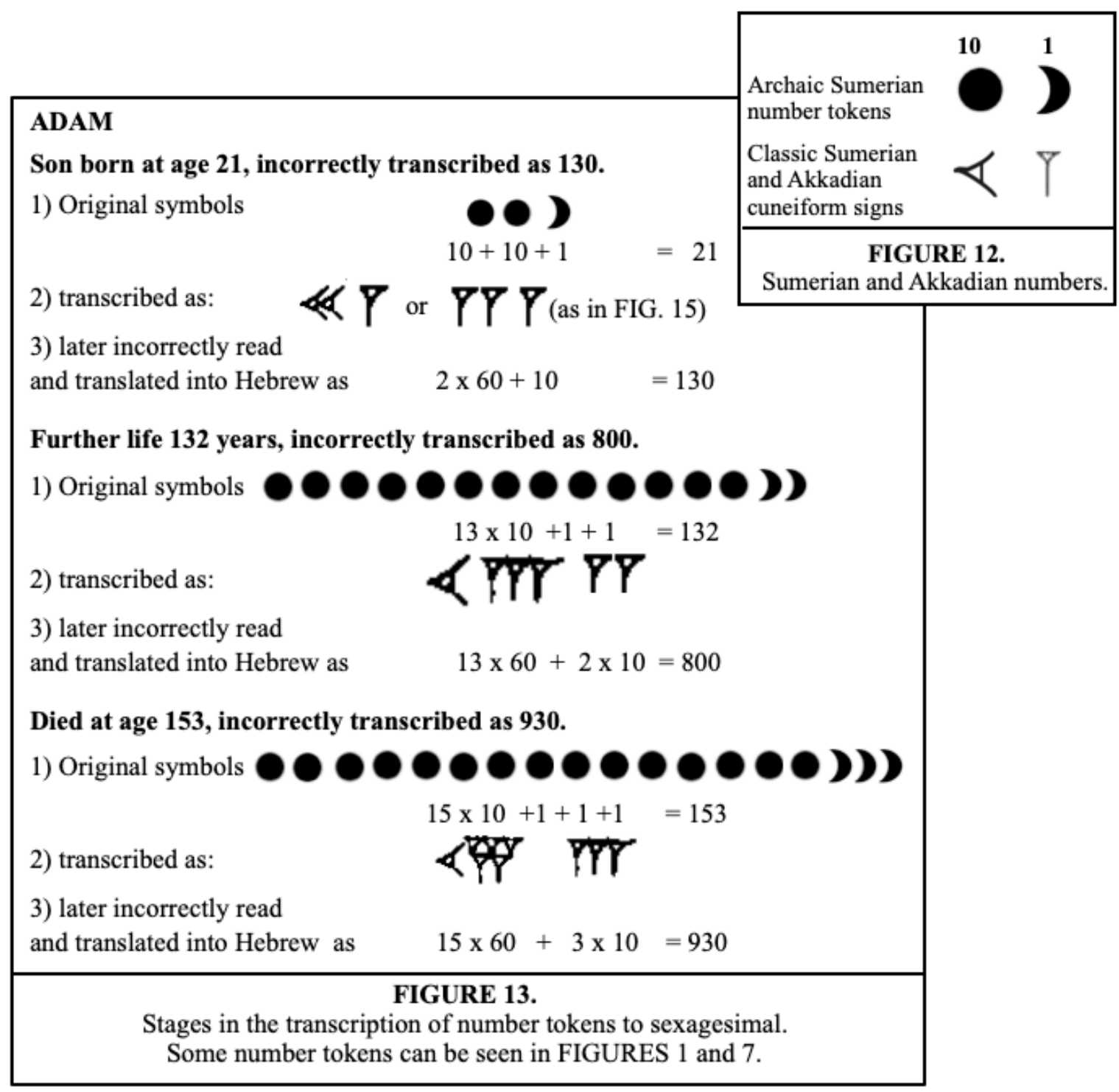

\section{2}

Transcription into cuneiform numbers - guesstimate: c. 2400-2000 BC

Perhaps five hundred years later, the tablet was copied into Classic Sumerian; the number tokens were transcribed as cuneiform wedges: Adam's son born at age, as two vertical wedges followed by a space followed by another wedge $=(2 \times 10)+1=21$. At this time the sexagesimal system had not been invented.

In the next several hundred years the tablet may have been copied and updated into Akkadian, (FIGURES 5 and 12) but with the number signs the same, the story is unchanged.

\subsection{Translation into Hebrew - guesstimate: c. $1350 \mathrm{BC}$}

This TABLET 3 (with the other tablets) was transcribed by Moses. He would probably have had the assistance of at least two scribes, to translate the cuneiform and write it down on papyrus in Egyptian and / or Hebrew.

\section{The sexagesimal transcription error}

When the scribe came to translate the tablet (FIGURE 13), he assumed they were the by then standard Akkadian sexagesimal numbers; he misread:
the son born at age as
$(2 \times 60)+10$
$=130$
the further life figure as
$(13 \times 60)+(2 \times 10)=800$
Adam's age at death as
$(15 \times 60)+(3 \times 10)=930$.

130,800 , and 930 are the Genesis ages. 


\begin{tabular}{|c|c|c|c|c|c|c|}
\hline \multirow[b]{3}{*}{ ADAM } & \multicolumn{3}{|c|}{$\begin{array}{c}\text { PROPOSED } \\
\text { ORIGINAL AGE }\end{array}$} & \multicolumn{3}{|c|}{$\begin{array}{c}\text { GENESIS 5 } \\
\text { AGE }\end{array}$} \\
\hline & $\begin{array}{l}\text { Son } \\
\text { born }\end{array}$ & $\begin{array}{l}\text { Further } \\
\text { life }\end{array}$ & $\begin{array}{l}\mathrm{r} \text { Died } \\
\text { at }\end{array}$ & $\begin{array}{l}\text { Son } \\
\text { born }\end{array}$ & $\begin{array}{l}\text { Further } \\
\text { life }\end{array}$ & $\begin{array}{l}\text { Died } \\
\text { at }\end{array}$ \\
\hline & 21 & 132 & 153 & 130 & 800 & 930 \\
\hline SETH & 14 & 139 & 153 & 105 & 807 & 912 \\
\hline ENOSH & 13 & 142 & 155 & 90 & 815 & 905 \\
\hline KENAN & 11 & 140 & 151 & 70 & 840 & 910 \\
\hline MAHALEL & 15 & 135 & 150 & 65 & 830 & 895 \\
\hline JARED & 30 & 132 & 162 & 162 & 800 & 962 \\
\hline ENOCH & 15 & 50 & 65 & 65 & 300 & 365 \\
\hline METHUSELAH & I 37 & 132 & 169 & 187 & 782 & 969 \\
\hline LAMECH & 32 & 100 & 132 & 182 & 595 & 777 \\
\hline NOAH 82 flood 1 & 100 & 55 & 155 & 500 flood 600 & 350 & 950 \\
\hline $\begin{array}{l}\text { Table showing } \\
\text { Numbers in i }\end{array}$ & italic & $\begin{array}{l}\text { osed } \\
\text { assur }\end{array}$ & $\begin{array}{l}\text { TABI } \\
\text { ges an } \\
\text { le an ac }\end{array}$ & $\begin{array}{l}\text { LE } 2 \text {. } \\
\text { d biblical ages b } \\
\text { dditional error ir }\end{array}$ & $\begin{array}{l}\text { before the } \\
\text { in transcri }\end{array}$ & $\begin{array}{l}\text { e Flood. } \\
\text { iption. }\end{array}$ \\
\hline
\end{tabular}

TABLE 2 shows the proposed ages for all the patriarchs down to Noah.

Being an honest fellow, and knowing that most readers are unlikely to check the calculations, I confess that the method works exactly for only 23 out of the 31 numbers.

The remaining eight numbers, which are shown in italics in TABLES 2 and 3, can be explained by a second space error when reading the cuneiform signs: a line of single wedges containing a space could be read as a group of tens and units.

For example, (the last paragraph in $\S 3.1$ is relevant);

1) Consider Mahalel's Genesis age at death, $895=(14 \times 60)+55$. Note (5) in TABLE 3.

2) We make a likely guess that he actually died at 150, in number tokens $1410 \mathrm{~s}$ and $101 \mathrm{~s}$.

3) The second error: the line of 10 wedges was read as 5 space 5 ; $(5 \times 10)+5=55$.

4) So Mahalel's age was transcribed as $(14 \times 60)+(5 \times 10)+5=895$.

This accounts for six of the remaining eight ages; in the last two cases notes (4) and (6) we assume that some wedges got worn away before the numbers were read (not unlikely considering lines 2, 3 and 4 in FIGURE 11), a somewhat laboured explanation but better than nothing.

Mathematically-minded readers can easily verify the calculations, detailed in TABLE 3. A spreadsheet (from cfjh1357@psmail.net, specify .numbers or .xlsx) does the work for you.

If the proposed ages and the transcription error are correct, in each case the age at birth of son plus further life should equal the age at death.

Check: the proposed numbers for Adam are 21, 132 and 153;

$21+132=153$; the proposed ages are consistent with each other.

All the other checksums are consistent, as shown in TABLE 3. 


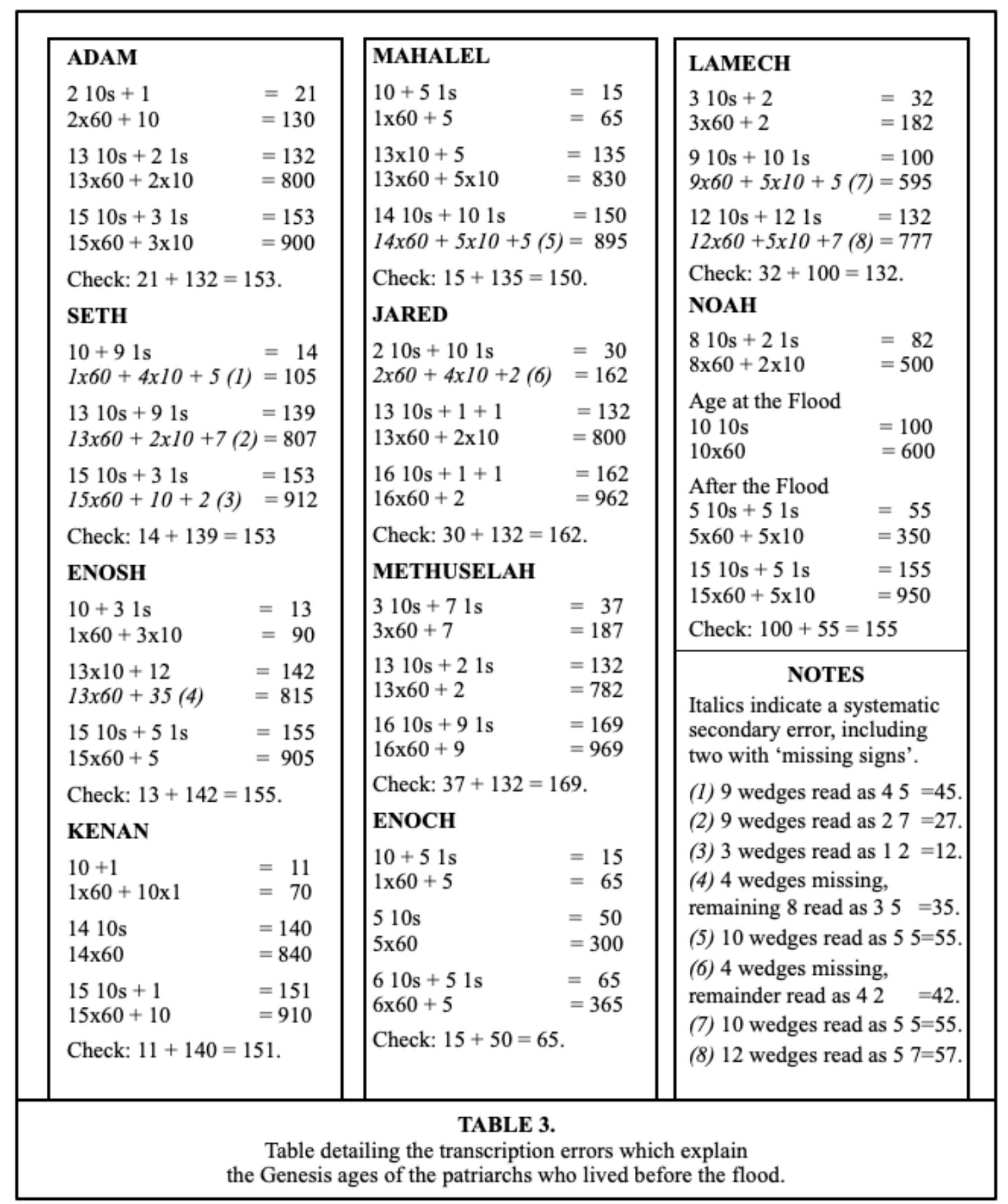

\subsection{Evaluation of the transcription error theory}

The cautious reader may wonder whether the author has cunningly selected numbers that happen to fit his theory.

\section{a. By analogy with deciphering an ancient language}

If the linguist discovers several examples of the form $\mathrm{NVX}$ where $\mathrm{N}$ is a noun, $\mathrm{V}$ is a verb and $\mathrm{X}$ is a suffix, four or five are usually considered sufficient to establish the grammatical formula. A few more of the form NVQX where $Q$ is an unknown sign would not invalidate the discovery.

In the case of these ages, no less than 23 are precisely explained by a known type of transcription error, and the remaining 8 with some additional reasoning. 


\section{b. By application of Bayes' Theorem (symbolic logic)}

A highly unlikely theory — in this case the transcription error theory — is true, if and only if, there is 'good reason' for selecting it out of the many equally unlikely theories. There are three 'good reasons':

- The development of cuneiform numbers which underlies the theory; this is common knowledge in the field and can be checked on Wikipedia.

- As (1) each patriarch's set of numbers in Genesis 5 is independent of the others and (2) the formula working on the proposed number sets accurately produces the Genesis 5 ages: in everyday scientific research this would be considered strong evidence that the proposed numbers together with the formula is a true explanation; and the fact that only $23 / 31$ of the proposed ages 'work' without an additional supposition would not invalidate the result.

- Inspection with some mathematical knowledge will confirm that each solution set producing the Genesis 5 ages is unique.

By conventional scientific standards the consistency of results is significant, and the explanation of the unlikely ages should be added to the other evidence for an EDI date.

\subsection{Why the unlikely ages remained in the Genesis text}

The proposed ages range from (son born at) 11 to (died at) 169, which are just within the bounds of possibility - bearing in mind that the original number token ages may not be accurate and have an unknown margin of error - while those in the Hebrew text are impossible $\mathbf{\$}$.

As noted in PART $1 \S 7.1$, the cuneiform scribe's job was to copy and/or translate. The content of a document — in this case the unlikely ages — was not his concern. In translating the signs precisely as he understood them, he was doing his professional job as a 'trained scribe'.

The ruling given before the flood in Gen. 6:3 'his [mans'] days will be 120 years', stating that after the flood human lifetimes would be reduced, from about 150 years rather than 900 , by $20 \%$ or so to a sexagesimal round number, fits neatly with the proposed transcription error and the pre-Flood lifetimes, and approximates to modern human lifetimes.

Like other biblical writers, Moses's knowledge was limited by his time and circumstances, as discussed in PART 1 §7.1.c. The phrase in the UCCF Basis of Faith 'as originally given' allows for these transcription errors.

\section{Conclusion}

Perhaps this transcription error is just an imaginative rigmarole; is it worth any more than the maths teacher's verdict on a student's attempted solution to a problem, 'A good try'?

But if the consistency of result confirms the transcription error, it clinches the case for the cuneiform origin of Genesis Chapters 1 to 5.

$* * * * *$ 


\section{GENESIS 1 - SIX CUNEIFORM TABLETS - SIX DAYS OF REVELATION}

$* * * * *$

We begin with the straightforward observation that Gen. 1:1-2:4 looks like a series of cuneiform tablets. FIGURE 14 shows that it neatly fits the pattern of a Sumerian document consisting of six tablets, numbered by the last sentence in each tablet — the nth day - and a colophon. The phrase the heavens and the earth is placed first to indicate it as the title or subject. (Word order varies between languages).

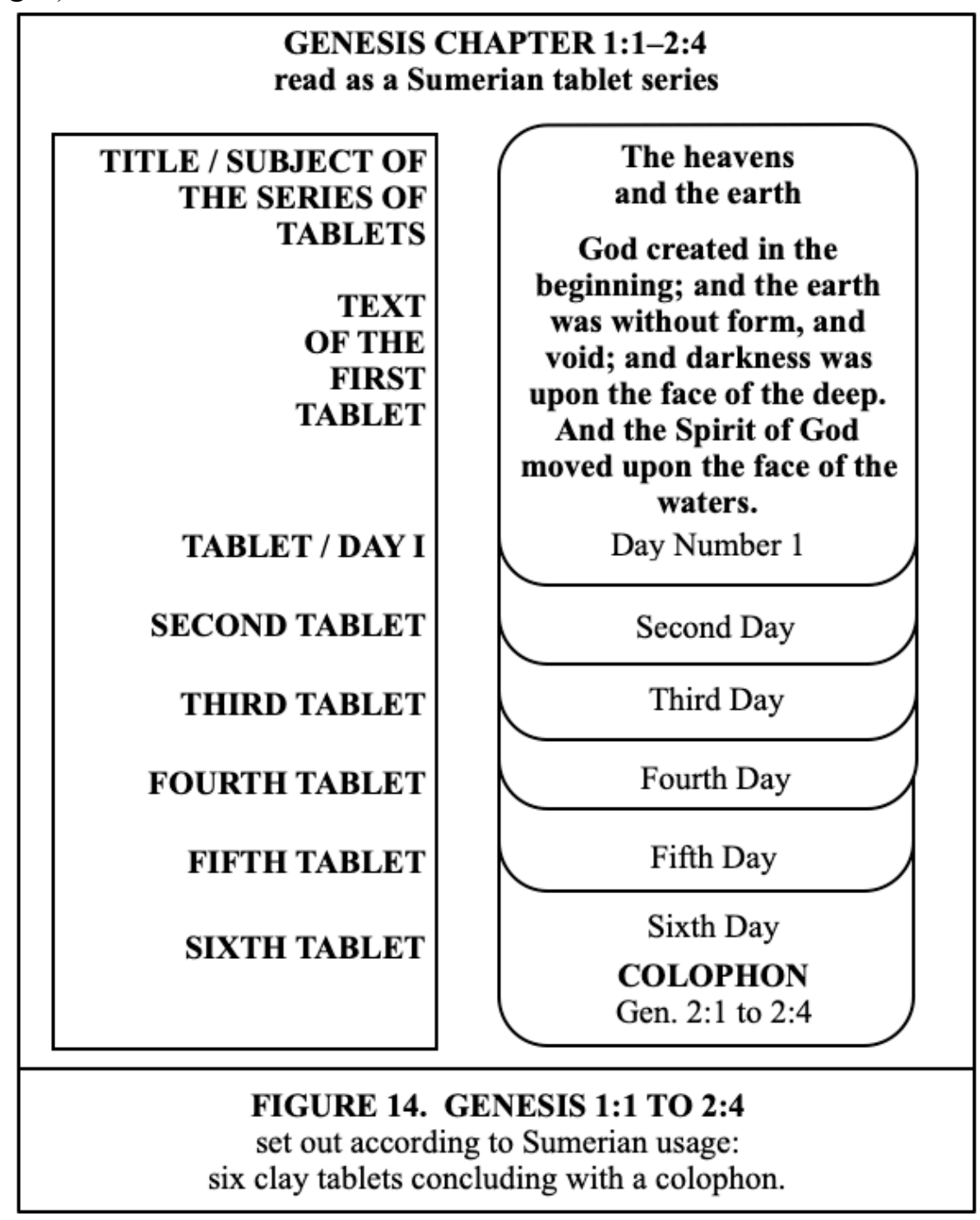

\section{Genesis 2:1-4 translated as a Sumerian Colophon}

\subsection{The uncertainties of reading Genesis 1:1-2:4}

The traditional translations and interpretations have several problems, debated inconclusively by generations of scholars from the Church Fathers to the present day:

- whether 24-hour days or age-days or a literary device or legendary;

- reconciling the six days with science,

- making good sense of Jesus's saying about the Sabbath;

- the meaning of tsaba in 2:1 is unclear;

- $\quad 2: 4$ says nothing meaningful.

Reading Genesis 1 as a Sumerian tablet writing resolves all these difficulties $\boldsymbol{}$ 


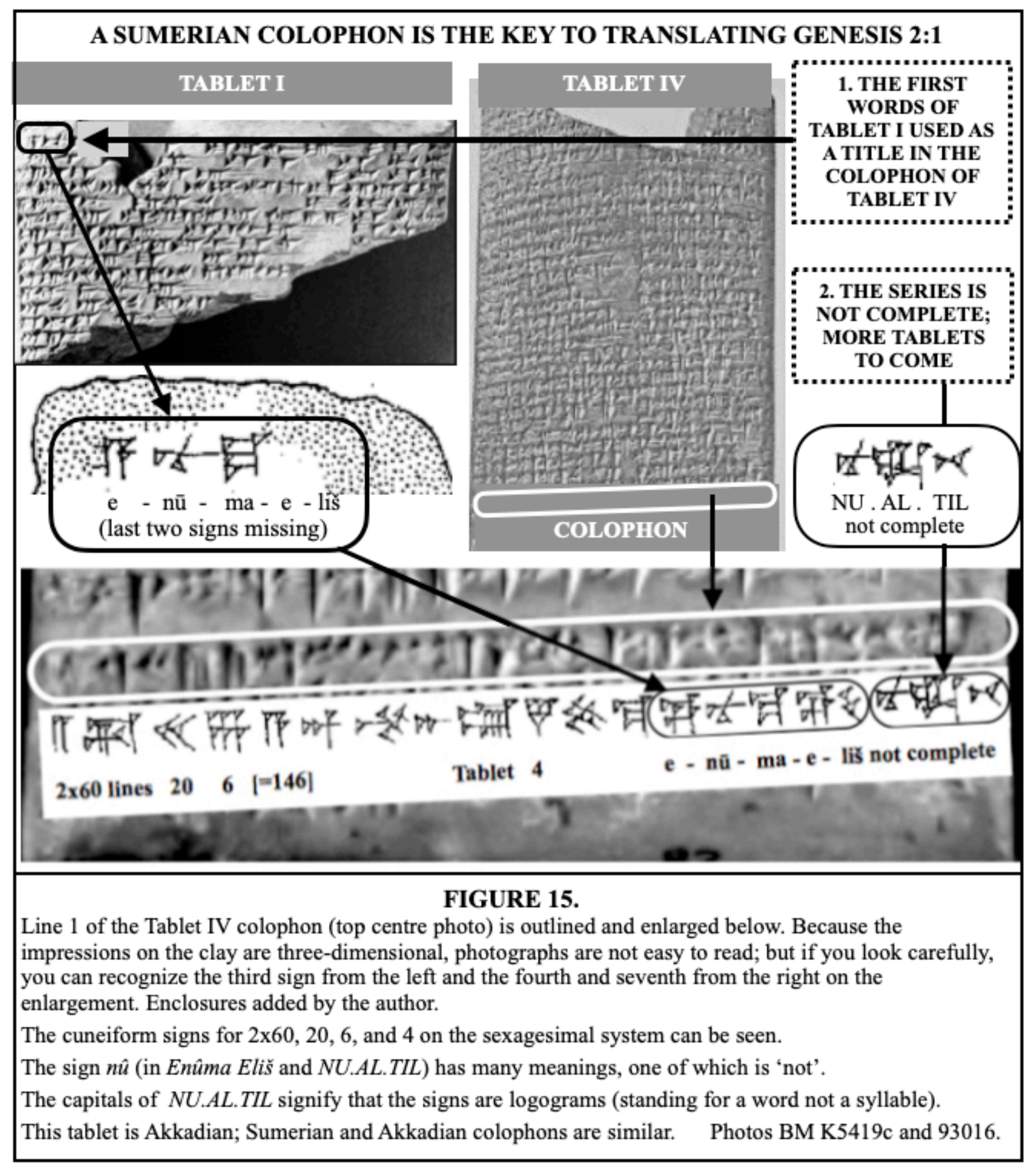

\subsection{Analysis of the first line of a typical Akkadian colophon}

See FIGURE 15. This line (also in FIGURE 6) is taken from Enuma Elish TABLET IV. ${ }^{82}$

1) Follow the arrow from the top right, noting that

- the first words of TABLET I are used as a title to refer to the whole series of tablets;

- the cuneiform signs state that the colophon is that of TABLET IV, and comes after 146 lines.

2) Follow the vertical arrow, noting that

- at the end of the line the last three signs NU.AL.TIL 'not complete' signify that there are more tablets to come. TABLET IV was the fourth out of six.

82 The cuneiform line art is taken from Cuneiform Texts from Babylonian Tablets \&c in the British Museum: Part XIII (1901): Plate 15, the second line after Line 146. <http://www.etana.org/sites/default/files/coretexts/17066.pdf. 


\begin{tabular}{|c|c|}
\hline ENUMA ELISH & GENESIS 1 \\
\hline $\begin{array}{l}\text { Six tablets numbered I to VI } \\
\text { This one is Tablet IV }\end{array}$ & Six tablets numbered I to VI $=$ Days 1 to 6 \\
\hline First words: 'Enuma Elish' & First words: 'The heavens and the earth' \\
\hline $\begin{array}{l}\text { Line } 1 \text { of the colophon of Tablet IV } \\
\text { uses the first words } \\
\text { to refer to the whole set of tablets } \\
\text { and says the series is 'not complete' }\end{array}$ & $\begin{array}{l}\text { Line } 1 \text { of the colophon Gen } 2: 1-4 \\
\text { uses the first words } \\
\text { to refer to the whole set of tablets } \\
\text { and says the series is 'complete' }\end{array}$ \\
\hline \multicolumn{2}{|c|}{$\begin{array}{l}\text { FIGURE 16. The series of tablets, not the universe, was completed. } \\
\text { Gen } 2: 1(\mathrm{AV}) \text { 'The heavens and the earth were completed'. } \\
\text { Sumerian literary usage shows that a better translation is } \\
\text { 'The heavens and the earth, this series of tablets, is complete.' }\end{array}$} \\
\hline
\end{tabular}

FIGURE 16 shows that Gen. 2:1 closely mirrors Line 1 of the Enuma Elish colophon.

\subsection{Genesis 2:1}

(AV) The heavens and the earth and all the host (tsaba) of them were finished.

In Gen. 1:1 the heavens and the earth is the title or subject of the writing, and in the colophon at 2:1 we find the very same words. This is the key that makes sense of Gen. 2:1 and 4: 'the heavens and the earth', according to the context, may refer either to the whole writing or to the physical universe. $A n-k i$ 'universe' is also found as $k i-a n$, so the reverse order in $2: 4 \mathrm{~b}$ is not significant.

Translators have found the meaning of tsaba obscure $\$$, rendering it variously as vast array or host or everything in them. The basic sense of the Hebrew is to arrange in order. ${ }^{83}$ What is there in the context that is arranged in order? - the series of tablets.

Next is something finished. A colophon usually stated whether the series was complete or there were more tablets to follow, as in FIGURES 15 and 16. What was finished? - not the universe but the series of tablets.

So following Sumerian usage, taking the root meaning of tsaba, and the heavens and the earth as the title, we paraphrase / translate Gen. 2:1:

'The heavens and the earth, this series of tablets, is complete.'

\section{a. Precisely what was finished? - speaking the content of the tablets}

Drawing attention to the repeated statement 'God said', P. J. Wiseman made the simple but revolutionary suggestion that what God had been doing was speaking, not creating.

Consider this sentence: 'At the end of the week, the Professor finished the creation of the universe.' What has the Professor finished doing? Has he been reading or writing a book, or making an astronomical toy for his grandchildren? Suppose we add context, and capitals and italics to indicate a title:

'At the end of the week, the Professor, who had been speaking about the natural world, finished the Creation of the Universe.' Clearly he has been teaching.

Now let us add the same context to Gen. 2:1:

'At the end of the week, God, who had been speaking about the natural world, finished The Heavens and the Earth.' God has not been creating but teaching about the creation of the universe.

83 R. Laird Harris, ed., Theological Wordbook of the Old Testament (Chicago: Moody, 1980): 750. 
Each tablet gives an account of what God said on that day - like the notes made by a student summarising a lecture. This understanding of Gen. 2:1 as part of a Sumerian colophon signposts an interpretation that integrates Genesis 1 with our scientific understanding of the universe.

\subsection{Genesis 2:2, 3}

Verses 2 and 3 are an addendum about the seventh day included in the colophon.

And on the seventh day God ended his work which he had made (asah); and he rested (shabath) on the seventh day from all his work which he had made (asah). And God blessed the seventh day, and sanctified it: because that in it he had rested (shabath) from all his work which God created (bara) and made (asah).

Both asah (do) and shabath (stop doing) can refer to a wide range of activity, like the English do. Having the Sabbath in mind, and not being over-concerned with relating the six days to natural history, the earliest translators made the reasonable — for their time - assumption that what God had been doing in the six days was creating the universe. So they translated asah as create and shabath as rested.

Translating shabath as rested implies that after six days of creating the universe the Almighty needed a break - a 'dormant anomaly' recognised by the NIV $\boldsymbol{\phi}$, which clearly has doubts about God getting tired, and by footnoting the root meaning ceased indicates that rested is a translator's inference. Instead of creation Wiseman suggested speaking or teaching as the stopped activity.

Paraphrase / translation of Gen. 2:2, 3:

And on the seventh day God completed his teaching; and he ceased on the seventh day the teaching that he had been doing. God blessed the seventh day, and made it holy, because in it he had finished the work of teaching about the creation which he had been doing.

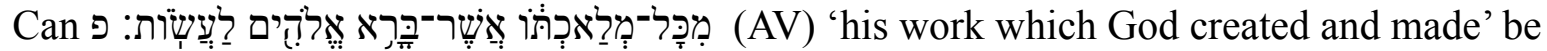
translated as 'teaching about the creation'? A Hebrew scholar naturally sees this as unjustified stretching of the text. But taking into account that (1) Sumerian often uses sequential pairs of verbs (2) and just as in English the range of reference of a general-activity word may include speaking, for example, make in 'the President made a speech', the common Sumerian sign $d^{u} g_{4}$ can mean speak as well as $d o^{84}$ and (3) it offers a meaningful translation in the context of the whole colophon, it may be allowed.

Genesis 2:4

These are the generations of the heavens and the earth when they were created (bara) in the day that the LORD God made (asah) the earth and the heavens.

The problem with this verse, in this and modern translations, is that it says nothing meaningful $\nrightarrow$. The NIV divides it in two and makes the second half an introduction to the following verses, but Sumerian usage suggests a better solution.

In the first part, if we take the heavens and the earth as the universe, we have 'This is the account of the creation of the universe' as a summary of the six tablets, an appropriate and straightforward rendering. 
The last part of the second half reads 'the Lord God did (asah) the earth and the heavens'. As in 2:1, the earth and the heavens, the title, stands for the set of tablets. We cannot translate asah as make because God did not make the tablets, nor as speak, because God did not speak the tablets. We could say that God spoke what was written in the tablets. But the tablets were not then in existence; so to avoid ambiguity we say that God spoke about what was summarised in the tablets, that is, the heavens and the earth, the creation. So we render God did the earth and the heavens as God revealed the knowledge of the creation.

A Sumerian scribe often noted the time or occasion of writing of the tablet. If we take in the day that as meaning at the time when, in accordance with the Sumerian grammatical construction (PART 1 \$4.2.h), we have a meaningful translation. ${ }^{85}$

Paraphrase / translation of Gen. 2:4:

This is the account of the creation of the universe, made at the time when the

Lord God revealed the knowledge of the creation.

There is no archaeological reason why this could not be an accurate statement. The Six Days could have taken place when writing was sufficiently developed to make the record.

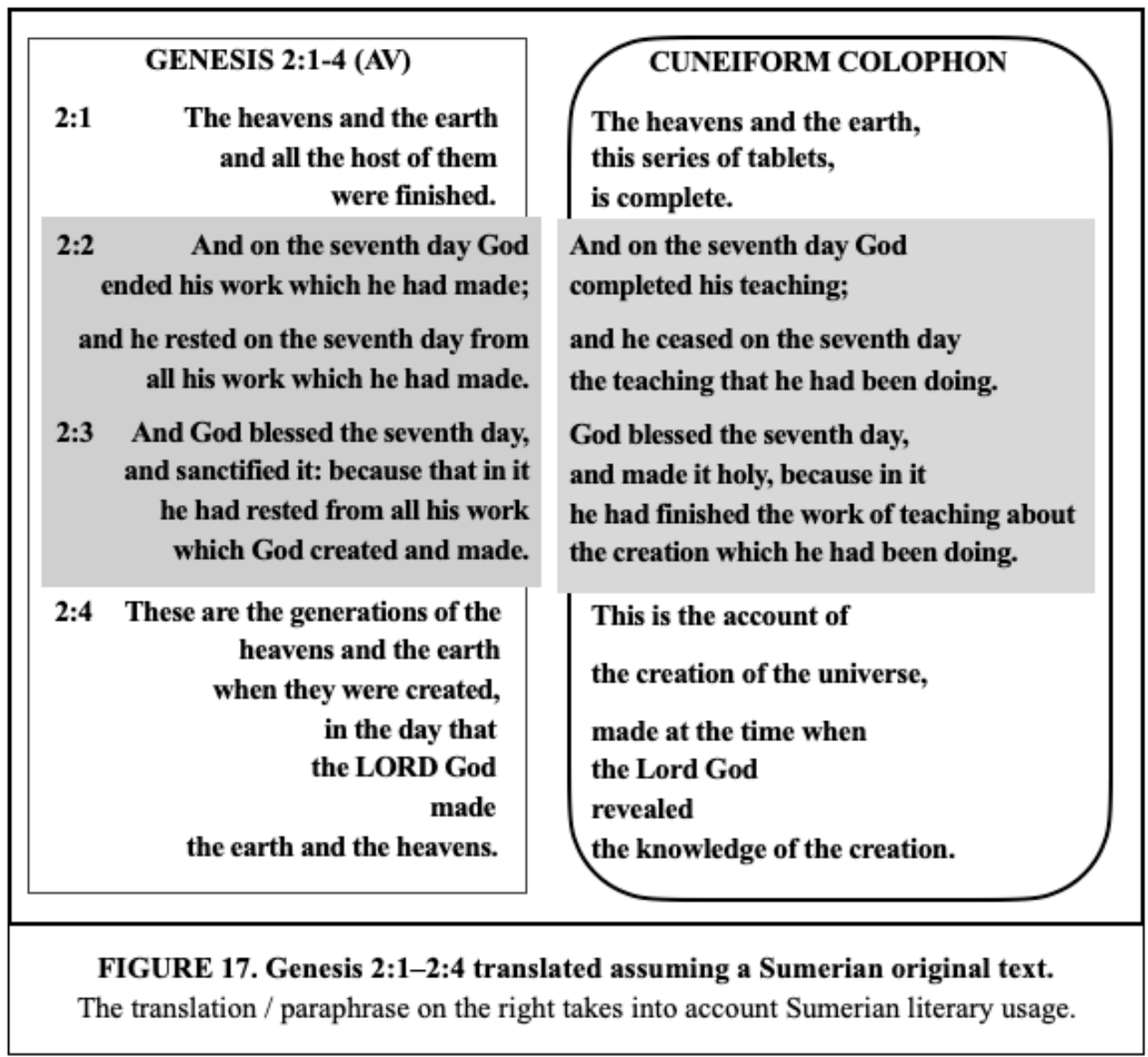

FIGURE 17 parallels this author's translation / paraphrase of Gen. 2:1-4 with the AV.

\section{The Six Days - Notes of a Real-time Seminar}

\subsection{Interpretation of the Six Days}

Genesis 1 reads more like a summary of an actual conversation than a stylistic device such as a vision or dream which puts words into God's mouth. 'And it was so' are the typical words of an eye-witness who has seen something planned actually happening. 
Several expositors have noted that it does not read like the visions in other parts of Scripture. 'According to the record, the author himself must have been a witness of the creation.' 86 'It consists of ... tableaux, which are represented before the eye of the mind, scenes from the creativity of God.' $87 \$ 3.1$ updates this insight into the age of twenty-first-century technology.

In Genesis 1 read according to Sumerian usage, we have the summaries of six seminar-style talks delivered over six normal days. At the end of the sixth day, the teaching God had been giving about the world that he had made was finished. It was not God but his listeners (perhaps a gathering of the clan) who appreciated the rest on completion of the six-day course, which makes good sense of Jesus's saying 'The Sabbath was made for man' (Mark 2:27) $\$$.

FIGURE 1 shows how the 'days' of the seminar would have been written at the time in Archaic Sumerian.

\subsection{Conservative authors on the Six Days}

We now consider the views in the three seminary textbooks discussed in PART 1.

Herbert M. Wolf agrees with Wiseman that 'The revelatory-day theory would sidestep most of the difficulties involved in reconciling science and Scripture', and that 'We are given the distinct impression that each day is describing what God accomplished on that day'; but assuming a visionary experience he discards it on the grounds that the account does not read like a vision; and also he takes rested as defining what God was doing on the seventh day — not considering that rested is merely a translator's inference from ceased. ${ }^{88}$

Victor Hamilton suggests 'God reveals himself to his people in a medium [a seven-day week] with which they can identify and which they can comprehend'. ${ }^{89}$ This paper suggests a seminar week rather than a literary week.

Alan Ross mentions six days of revelation as a possibility but without discussion opts for creation in six literal days. ${ }^{90}$

None of these authors weighs the significance for the interpretation that Gen. 1:1-2:4 parallels a typical series of cuneiform tablets with a colophon $\$$. The reader may consider it relevant that none of them is a cuneiform scholar.

On the other hand, Bernard Ramm concluded 'that creation was revealed in six days, not performed in six days'. ${ }^{91}$

\section{a. Walton versus (P. J.) Wiseman}

Both authors start with a tabula rasa for Genesis 1, free from pressures of concordism and academic tradition. Both claim to read the text as ancient literature. Wiseman (and this author) present it as an Early Bronze Age revelation, a line-drawn picture on a clear white canvas; Walton presents it as a Middle Bronze Age revelation, painted on a wall of colourful graffiti. Attention to cuneiform archaeology accounts for the difference.

A cuneiform origin of Genesis 1 strongly supports but does not require the Six Days interpretation. The early date and simple monotheism rule out influences of the Akkadian epics and

86 Christoph Friedrich von Ammon, Repertorium (c. 1830): IV, 131.

87 Johann H. Kurtz, Die Astronomie und Die Bibel, tr. of 3rd German edn. (1857): 110.

88 Wolf, 87-88.

89 Hamilton, 56.

90 Ross, 28.

91 Ramm, 151. 
polytheist world-view assumed by many authors and the general public.

\section{The Six Days and Science}

Unlike the objective evidence for a date for Genesis 1, the interpretation is dependent on the worldview of the reader. This author makes a personal choice to understand the text on the basis of the Christian theist world-view, leading to the interpretation that over six days the Creator God instructed a group of early Sumerian speakers about the world he had created for them to live in.

\subsection{The basis of conflict removed}

The pre-19th-century understanding of the Hebrew text was that God during six days created the world, and at the end of the six days his work of creation was finished. Christians have always had difficulty integrating observations of the natural world with what appears to be a sequential account of creation + . In the last two hundred years, endless geological, cultural, and literary speculation, and micro-analysis of the Hebrew text, have produced no agreement on how to reconcile Genesis 1 with science.

But given the translation of Gen. 2:1 in accordance with Sumerian literary structure as 'The heavens and the earth, this series of tablets, is complete', the whole basis of interpretation is changed. The temporal sequence of the days no longer portrays a series of divine operations to be matched against scientific discoveries $\boldsymbol{\$}$, but a series of daily talks about the natural world.

The BBC TV series Planet Earth presents amazing video photography of the natural world without mention of speciation or geological ages. In each day God gives his seminar group an audiovisual presentation (with time-lapse photography?) of an aspect of his creation. For example,

We can picture what they see [in Day 1, as though in a helicopter or paragliding]: they cruise around at a great height and look down towards the earth far below. All is dim and the air is murky, there is no horizon, only an impression of a vast and empty watery expanse. But there is a warm, homely feeling and a sense of anticipation, for the Spirit of God is hovering over the waters. Then God says 'Let there be light'. As the sun moves up towards the horizon, the dawn displaces the darkness. The sun rises, burns off the mist and the day begins. ${ }^{92}$

When Genesis 1 is seen as a series of phenomenological and theory-free audiovisual presentations of aspects of the natural world, there is no conflict with science.

\subsection{Science in Genesis 1}

In the seminar God gives them words for natural phenomena; words for things they can see begin to illuminate their simple and uninformed minds and enable them to think about their world. In a natural science class with small children we show them something and teach them the word for it. In Genesis 1 we have a similar introduction to science - how to observe and name and think about natural phenomena. Is this a hint of how God taught an early group of villagers to understand the natural world? Could this explain the unusually prolific inventive culture of the Sumerians?

\footnotetext{
92 An extract from this author's An Imaginative Exposition of Genesis 1.
} 


\section{ACTION}

Observe and name:

Classify in groups:

Distinguish differences:

Collate observations:

Classify in sub-categories:

Name objects:

and abstract concepts:

\section{EXAMPLES}

the objects in sky, land, and sea.

plants, trees, animals, birds and sea creatures.

the bigger light and the smaller light;

sea creatures observed to be of many different types,

also birds of many kinds,

animals, having the breath of life, distinguished from plants.

living creatures naturally multiply;

and breed true after their kind.

Trees reproduce by seeds;

fruits have seeds inside.

flora: seed-bearing plants, trees bearing fruit with seeds;

fauna: ground-living creatures,

livestock,

wild animals.

sky, land, seas;

day and night,

light and darkness.

\section{b. A framework for understanding space and time}

Observe and think about

space: the sea and sky,

the distant sun, moon and stars.

and time: 93 the point origin of the universe in the beginning;

the arrow of time, ${ }^{94}$ with its cycles:

the sun $\quad$ - daily cycle;
the moon $\quad-$ monthly cycle;
the stars $\quad$ - annual cycle, paralleling the seasons;
the life sequences of animals.

Discern logical connections (given the purpose of the creation):

morning-and-evening provide a framework for everyday life;

the sun and moon govern = determine the length of day and night;

and give light suitable for man's work and sleep;

plants and fruit trees provide food for man.

\section{c. A framework for life}

A world-view for interpreting observations of the world:

- The universe was created by God,

- from nothing.

- The world is designed by God,

- for the benefit of man.

93 Augustine discerned the intimate connection of space and time, long before Einstein: 'Non est mundus factus in tempore, sed cum tempore.' 'The world was not made in time, but with time.' Civ. 11:6.

94 A cosmological concept implied in Genesis 1; the phrase was coined by Sir Arthur Eddington in The Nature of the Physical World (Cambridge: Cambridge University Press, 1928): 35. 
Modern science (provided it is dissociated from humanist and reductionist presuppositions) fits neatly with this early world-view. Thus, the comparatively recent discoveries of the expansion and the fine-tuning of the universe - that the universe came into existence at a definite time in the past, and that many conditions necessary for life to exist, such as that the earth is neither too near nor too far from the sun - confirm and give precision to the general ideas expressed in these clay tablets from the dawn of civilisation. Even the atheist Professor Stephen Hawking conceded that the world-view of Genesis 1 is observationally true 'The universe appears to be designed for the existence of life'. ${ }^{95}$ Coherence with wide-ranging observation is a good test of a world-view.

Compare and contrast this systematic and accurately observed survey of the natural world and introduction to scientific thought in these Sumerian clay tablets with non-Judaeo-Christian cultural ideas. Admitting the historically rare scientific work of individuals, for instance, Imhotep (Egypt 2600 BC), the inventor of the calculus (Babylon 1800 BC), Thales (Greece 600 BC), Aristotle (Greece 400 BC), Ibn Al-Haytham (Egypt AD 1000), and assorted astronomers, Roman technology and Chinese horticulture, the pre-Christian Era polytheistic cultures and preReformation Europe generally promulgated superstitious and hopelessly inaccurate treatments of nature.

R. Hookyaas ${ }^{96}$ and Vishal Mangalwadi 97 in their extensive reviews of science in earlier cultures, and Peter Harrison similarly, ${ }^{8}$ argue convincingly that modern science arose as a consequence of the biblical Christian world-view disseminated by the Reformation. This worldview incorporates a feature of the universe on which all scientific research depends, noted by Albert Einstein as worthy of explanation but taken for granted by Stephen Hawking 'The most incomprehensible thing about the universe is that it is comprehensible'; 99 of which the explanation, neatly expressed in a children's' hymn, is 'He gave us eyes to see them'. 100

The Christian world-view supplies a foundation for science which the Enlightenment paradigm of gradual development and upward progress neither provides nor accounts for - an answer to the question 'How is it that man is able to think about, appreciate, understand and control nature?' or 'How is science possible?' - from the Sumerian clay tablets of Genesis 1:

'Because both man and nature come from the Word of the same Maker.'

\section{The Double Paradigm Shift}

PART 1 argued from the archaeological and textual evidence, namely the development of writing, cuneiform literary structure, contemporary writing and accurate cultural knowledge, for the cuneiform origin of Genesis. PART 2 adduced supporting evidence. This is the first paradigm shift.

In PART 3 a second paradigm shift has been proposed, that what was finished in Gen. 2:1 was not the creation of the universe but a spoken presentation about the natural world, delivered over six ordinary days, at a time when writing was sufficiently developed to record it in summary

\footnotetext{
95 Stephen Hawking and Leonard Mlodinov, The Grand Design (London: Bantam, 2010): 164.

96 'Most scientists of the nineteenth and twentieth centuries ... [were] unconscious of the fact that the metaphysical foundations of their discipline stemmed ... from the biblical concept of God and creation.' R. Hookyaas, Religion and the Rise of Modern Science (Edinburgh: Scottish Academic Press, 1973): 26.

97 Vishal Mangalwadi in The Book That Made Your World - How the Bible Created the Soul of Western Civilisation (Nashville: Nelson, 2011): 220-245, gives examples of how the Buddhist, Hindu and Muslim world-views inhibited growth of the scientific method.

98 Peter Harrison,'Religion and the Rise of Science', Faraday Institute 21 (2021).

99 'Das Unbegreiflichste am Universum ist, dass es verständlich ist.' Albert Einstein in 'Physik und Realität', Journal of the Franklin Institute (1936): 313-347.

100 'All Things Bright and Beautiful' by Cecil Frances Alexander, (1848).
} 
form on clay tablets. The old paradigm assumption of a 'long period of oral transmission' has no evidential base.

A new paradigm always feels strange. The idea that light could have both wave and particle properties seemed an impossibility to scientists in the $1920 \mathrm{~s}$, but the new, weird, quantum theory made sense of the observations, and is now accepted as scientific truth.

'Simplex sigillum veri, the simple is clear and distinct. Next to simplicity unity is a sign of truth.' 101 The simple cuneiform hypothesis unifies Genesis 1 with the rest of Genesis, and science.

The cuneiform theory and Six Days makes surprisingly good sense - the penny-droppingpoint of a new paradigm. Six Days of Revelation, based on the archaeological facts, leads to a coherent understanding of the whole chapter; it does not conflict with any Christian doctrine or any archaeological or scientific discovery. The Sumerian literary usage explains and fits the text so well, that it is a simple and straightforward conclusion that the Six Days were six normal days of spoken instruction.

\section{Summary of the evidence for Six Days of Revelation}

Genesis 2:1-2:4, translated in accordance with Sumerian usage, makes good sense:

- 'the heavens and the earth' is a title so may refer either to the writing or the universe;

- thus in 2:1 the writing, the set of tablets, was finished, not the creation of the universe;

- in 2:2 and 2:3, the Hebrew text merely states that God stopped doing whatever he was doing, which was over six days speaking ('God said') what was later written in the tablets.

- In 2:4, 'in the day that' refers to the time when God did the series of tablets; that is, to the six normal days during which he spoke this information about the world he has made.

\section{Conclusion}

As the archaeologists uncovered the ancient cities and the linguists deciphered the tablets, our understanding of the language and culture of the patriarchs has gradually advanced from ignorance to a substantial knowledge-base, that now gives us further insight into Genesis 1.

In the Six Days of Revelation we have been given

the words of the Master not whispers from prehistory,

the lessons of the Teacher recorded as students' notes, a tutorial by the Creator about our space-time world.

We could call it the Earth Life Seminar.

$* * * * *$

101 Jürgen Moltmann, 'From Physics to Theology - A Personal Story', Science and Christian Belief 24(2) (2012): 99-109, esp. 106. 


\title{
OVERVIEW
}

\section{THE CUNEIFORM ORIGIN OF GENESIS AND A DATE FOR GENESIS 1}

\author{
PART 1 \\ GENESIS 1:1 TO 37:2A WAS WRITTEN IN CUNEIFORM AND \\ (EXCEPTING CHAPTERS 1 TO 4) \\ AT ABOUT THE TIME OF THE EVENTS RECORDED

\section{This Sumerian Clay Tablet Initiates a Paradigm Shift}

\section{Paradigm Shifts}

2.1 The current paradigm has many 'dormant anomalies'

2.2 Contrary evidence is excluded by

a. academic groupthink

b. neglect of archaeology

3. Evidence for an Early Dynastic I Date for Genesis 1:1-2:4

3.1 Writing was in use before the flood

3.2 The Bronze Age Sumerians c. 4000-3000 BC

3.3 Archaic Sumerian - the written language of Genesis 1:1-6:9a

3.4 A 'written account' in Early Dynastic I

3.5 The written language of Genesis 6:9b to 37:2a

4. Evidence for Contemporary Writing of Genesis 5:2-37:2a

4.1 Internal evidence

a. Each named person could have written the section preceding his name

b. The death of the named person is recorded in the next tablet

c. Many of the Genesis stories are first-person or eye-witness accounts

4.2 Archaeological and linguistic evidence
a. Genesis 4:22-5:1 - the 'written account'
b. Genesis 4:17-5:32 - the Babylonian King Lists
c. Genesis 10 - Ethno-geographical information
d. Genesis 10:19 - Sodom and Gomorrah
e. Genesis 11:3 - the Tower of Babel
f. Genesis 16:2 - Sarah and Hagar
g. Accurate incidental cultural details
h. Traces of Sumerian in the English Bible

\section{Evidence that the toledoth are Sumerian or Akkadian Colophons}

5.1 The literary usage of cuneiform colophons

5.2 The toledoth have many features of cuneiform colophons

5.3 'Dormant anomalies' disappear in the light of Sumerian usage

5.4 The ages of the antediluvian patriarchs explained

5.5 The internal evidence

5.6 The evidence assembled

\section{Academic Opinion on Colophons}

6.1 Academic support for P. J. Wiseman

6.2 Academia against Wiseman

a. The colophons are inconsistent with one another

b. The colophons are not as clearly defined as claimed

c. Moses couldn't read cuneiform

d. Quarrelling brothers wouldn't cooperate

e. The 'written account' is impossible

f. Unity of theme or purpose

6.3 Conclusion of the colophon debate 


\section{Source Criticism of the Cuneiform Text}

7.1 The Sumerian 'trained scribe'

a. The 'trained scribe' — variant accounts

b. The 'trained scribe' - the Flood narrative

c. The 'trained scribe' — the local flood and the 'one language'

d. Another Sumerian literary custom

7.2 Moses, the underrated historian

\section{Summary of the Arguments for the Paradigm Shift}

8.1 The JEDP paradigm ignores significant archaeological and literary evidence 8.2 The JEDP paradigm lacks positive archaeological evidence

8.3 The paradigm shift explains many 'dormant anomalies'

8.4 Summary of the evidence that Genesis 1:1-37:2a has a cuneiform origin

\section{A Reasonable Conclusion}

PART 2

A TRANSCRIPTION ERROR EXPLAINS

THE AGES OF THE PATRIARCHS BEFORE THE FLOOD

\section{A New Solution to an Old Problem}

2. Writing and Numbers from Sumerian to Akkadian

2.1 Sumerian

2.2 Akkadian

\section{The Akkadian Sexagesimal System}

3.1 The Sexagesimal Place Value Notation (SPVN) system

3.2 The Akkadians had no zero

3.3 Misreading a zero space could cause a large error

\section{The Stages in the Transmission of Noah's Genealogy down to Moses}

4.1 The genealogy first written down

4.2 Transcription into cuneiform numbers

4.3 Translation into Hebrew
- guesstimate: c. $2800 \mathrm{BC}$

- guesstimate: c. 2400-2000 BC

- guesstimate: c. $1350 \mathrm{BC}$

\section{The Sexagesimal Transcription Error}

5.1 Evaluation of the transcription error theory

a. By analogy with deciphering an ancient language

b. By application of Bayes' Theorem (symbolic logic)

5.2 Why the unlikely ages remained in the Genesis text

6. Conclusion 


\section{Genesis 2:1-4 Translated as a Sumerian Colophon}

1.1 The uncertainties of reading Genesis 1:1-2:4

1.2 Analysis of the first line of a typical Akkadian colophon

1.3 Genesis 2:1

a. Precisely what was finished? - speaking the content of the tablets

1.4 Genesis 2:2, 3

1.5 Genesis $2: 4$

\section{The Six Days - Notes of a Real-time Seminar}

2.1 Interpretation of the Six Days

2.2 Conservative authors on the Six Days

a. Walton versus (P. J.) Wiseman

3.1 The basis of conflict removed

3. The Six Days and Science

3.2 Science in Genesis 1

a. A framework for scientific study of the natural world

b. A framework for understanding space and time

c. A framework for life

\section{The Double Paradigm Shift}

5. Summary of the evidence for Six Days of Revelation

\section{Conclusion}

$$
==\mathbf{=}=\mathbf{=}
$$

The author may be contacted at cfjh1357@psmail.net

$$
=====
$$

\section{NOTES ON READING 'THE CUNEIFORM ORIGIN OF GENESIS etc'}

No reviewer or reader so far has faulted this paper on any substantive issue.

1. A proposed paradigm shift always seems crazy because it contradicts the conventional wisdom. It is unfashionable and always at first rejected by the intellectual elite - remember Galileo? A new paradigm is difficult to evaluate because the theory is outside ones working experience and there are few papers with which to compare it - in this case, only one.

2. This paper is neither abstruse nor highly technical; several of the 'lines of evidence' (page 19) can be checked by anyone with an English bible. It only appears so because of the clay tablet illustrations, and because parts are not in the reader's field. The complex FIGURES 11 and 15 are merely illustrations, not proofs, of known facts stated in simple English.

3. Nothing rests upon a new discovery or a controversial clay tablet. The author has integrated well-established information, all referenced, from cuneiform and Ancient Near East (ANE) and Pentateuchal studies most of which has been discussed in the journals for decades, to argue his thesis. All translations from Sumerian or Akkadian are cited from a museum or cuneiform expert.

You don't cite a paper by a Professor of Astronomy for the properties of the planets; nor one by a Professor of Assyriology to prove that Archaic Sumerian used number tokens C. 2800 BC (FIGURE 8), Classic Sumerian used wedges and base-10 c. 2400 BC (FIGURE 9), the base-60 system was introduced c. 2000 BC, and Moses lived C. 1350 BC. These four 
assumptions that underlie the explanation of the ages in Genesis 5 (PART 2) are common knowledge in the ANE field and easily checked from general articles in Wikipedia.

4. The paper covers Sumerian artefacts and language, the Hebrew text of Genesis, conversion of base-60 numbers, JEDP, and philosophy of science. A multidisciplinary thesis requires collaboration; an editor could arrange for several scholars to review what lies within their areas of knowledge and collate the results.

Some authoritative comment on the Sumerian aspects exists: the internationally respected Assyriologist Professor Donald Wiseman gave expert authentication to many of the Sumerian points in Science \& Christian Belief (1991), 3: 25-34, cited in the paper. As far as I know, no Sumerian scholar has refuted him in any journal, and no other cuneiform expert has written about Genesis 1.

In PART 2 (the ages of the patriarchs) scientific or mathematical knowledge is needed to review the calculations and evaluate the strength of the argument (a simple job that would take about an hour), assuming the dates and number tokens assumptions are correct.

5. As a reader will wish to know what is claimed as new, but may not recognise new ideas in fields outside his own, these are points that the author claims as original:

- The tablet in FIGURE 1 illustrating how the 'days' in Genesis 1 could have been written (page 1);

- a paradigm shift to replace JEDP (pages 2, 3,18-19);

- resolution of 20+ 'dormant anomalies' in JEDP (pages 3, 9-10, 14 and elsewhere);

- Genesis 1 could have been written in Archaic Sumerian, in ED1 (pages 6 and 7);

- the connection of the 'written account' in Genesis 5:1 with the invention of writing in ED1, and the inventions in Genesis 4 with their invention in EDI (page 7);

- $\quad$ the proposed date for Genesis 1 of $2850 \pm 150$ BC (page 7);

- Abraham was an educated man (page 7);

- the 'traces of Sumerian in the English Bible' (pages 11-12);

- the Sumerian 'trained scribe' (pages 17 and 27);

- Moses, the underrated historian (page 18);

- the transcription error to explain the ages in Genesis 5 (PART 2, pages 21-27);

- the professor analogy (page 30);

- the paraphrase / translation of Genesis 2:1-4 (pages 30-32);

- the 'frameworks for science' in Genesis 1; (page 35);

- FIGURES 1, 2, 5, 10-17, and TABLES 1-3.

6. The author hopes you will agree that considering that writing, of the Sumerian language, was invented c. $3000 \mathrm{BC}$, in Sumer where the patriarchs lived and where Sumerian epics are known from $2600 \mathrm{BC}$, the theory that Genesis 1 might have been written in Sumerian between those two dates is not obviously far-fetched, and is a suitable subject for academic discussion.

$$
=\text { = }=\text { = = }
$$




\section{MIT License}

Copyright (c) 2021 Carey Francis John Harmer

Permission is hereby granted, free of charge, to any person obtaining a copy of this software and associated documentation files (the "Software"), to deal in the Software without restriction, including without limitation the rights to use, copy, modify, merge, publish, distribute, sublicense, and/or sell copies of the Software, and to permit persons to whom the Software is furnished to do so, subject to the following conditions:

The above copyright notice and this permission notice shall be included in all copies or substantial portions of the Software.

THE SOFTWARE IS PROVIDED "AS IS", WITHOUT WARRANTY OF ANY KIND, EXPRESS OR IMPLIED, INCLUDING BUT NOT LIMITED TO THE WARRANTIES OF MERCHANTABILITY, FITNESS FOR A PARTICULAR PURPOSE AND NONINFRINGEMENT. IN NO EVENT SHALL THE AUTHORS OR COPYRIGHT HOLDERS BE LIABLE FOR ANY CLAIM, DAMAGES OR OTHER LIABILITY, WHETHER IN AN ACTION OF CONTRACT, TORT OR OTHERWISE, ARISING FROM, OUT OF OR IN CONNECTION WITH TORT OR OTHERWISE, ARISING FROM, OUT OF OR IN CONNECTION WITH THE SOFTWARE OR THE USE OR OTHER DEALINGS IN THE SOFTWARE. 